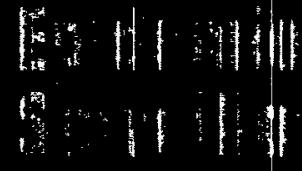

\section{Enidemiologio Surveillinine}

Epidemiologio Surveilltinee

Annual Report for

Idiho

Notional

Engineering

Liboralory
H. Hill

Epidemiologic Surveillines

Epidemiologic Surveillance

If.

gut Hello:
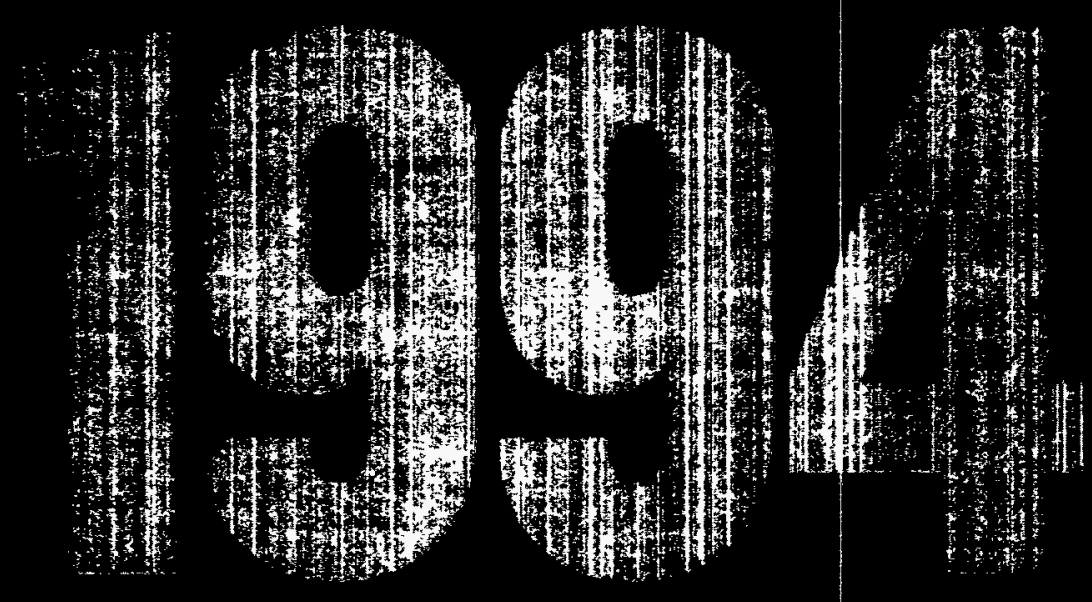

Epidemiologio Surveillannee Epidemiologic Surveillinee

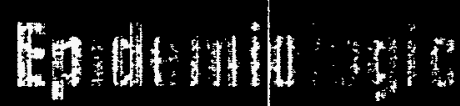

Survellightot

Epidemiologic Surveillinge

Prepared by the Epidemiologic Surveillance Data Center, a joint program of the Oak Ridge Institute for Science and Education in conjunction with the Office of Epidemiologic Studies, U.S. Department of Energy 
This report was prepared by the staff of the Center for Epidemiologic Research, within the Environmental and Health Sciences Division of the Oak Ridge Institute for Science and Education in conjunction with the Office of Epidemiologic Studies, U.S. Department of Energy.

Questions or comments may be directed to:

Dr. Bonnie Richter or

Dr. Cliff Strader

U.S. Department of Energy

Office of Epidemiologic Studies

Mail Stop: 270CC/EH-62

19901 Germantown Road

Germantown, MD 20874-1290

This annual report is sponsored by the U.S. Department of Energy. It is based on information submitted by participating laboratories. The views and opinions expressed in this report are those of its authors and do not necessarily reflect the views of the U.S. Government, its agencies, or its employees.

\section{Tuble of Contents}

Foreword . .1

INEL at a Glance: 1994

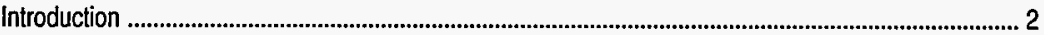

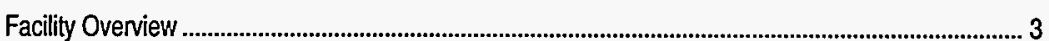

Labor Force by Occupational Category and Salary Status, 1994 .......................................................... 4

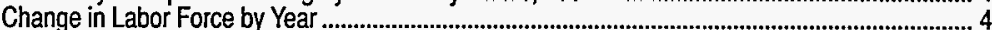

Absences Among Work Force, 1994 ............................................................................................ 5

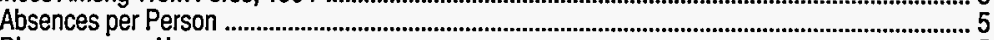

Diagnoses per Absence ................................................................................................ 5

Diagnosis Rates for Absences .................................................................................................

Diseases and Injuries by Diagnostic Category, 1994 ................................................................................6 6

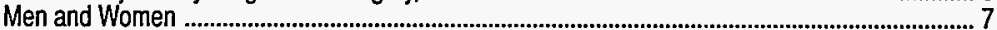

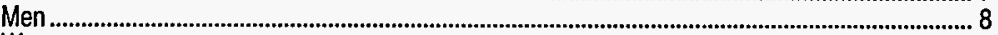

Women

Diagnoses Associated with Pregnancy, Labor, and Delivery .......................................................... 10

Diagnoses by Occupational Category, 1994 ........................................................................................... 10

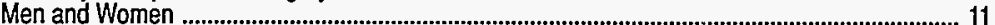

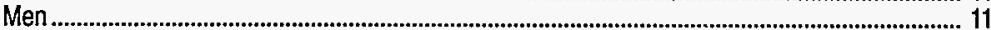

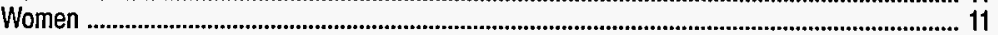

Deaths Among Active Workers, 1994 .............................................................................................. 12

Relative Risk for All Diseases and Injuries by Occupation ................................................................ 12

Relative Risk for Selected Disease and Injury Categories by Occupation ............................................ 14

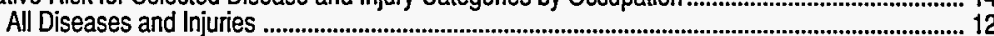

Infections and Parasitic Diseases .................................................................................................. 12

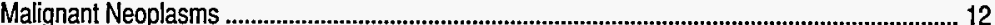

Benign Neoplasms ............................................................................................................... 12

Endocrine and Metabolic Diseases .................................................................................. 12

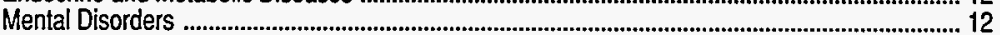

Diseases of the Nervous System and Sense Organs .................................................................... 12

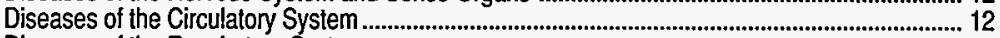

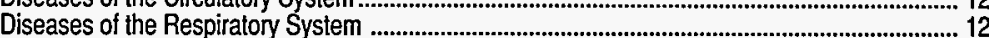

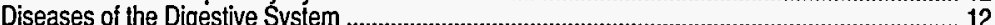

Diseases of the Genitourinary System ....................................................................................... 12

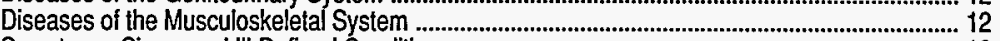

Symptoms, Signs, and III-Defined Conditions ...................................................................................... 12

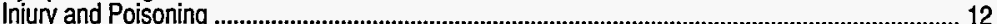

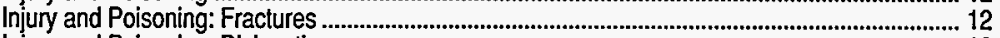

Injury and Poisoning: Dislocations ........................................................................................... 12

Injury and Poisoning: Sprains and Strains ........................................................................... 12

Injury and Poisoning: "Other" Injuries .......................................................................................... 12

OSHA-Recordable Events Among INEL Employees, 1994 ................................................................... 15

OSHA-Recordable Events per Person

Diagnoses per OSHA-Recordable Event ......................................................................................... 15

Diagnosis Rates for OSHA-Recordable Events …………...................................................... 15

OSHA-Recordable Diseases and Injuries by Diagnostic Category, 1994 .......................................... 16

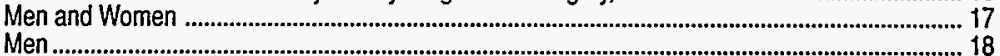

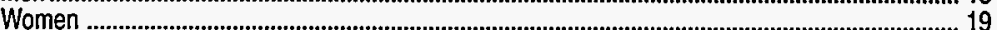

OSHA-Recordable Diagnoses by Occupational Category, 1994 ........................................................... 20

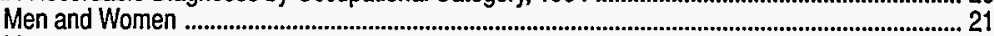

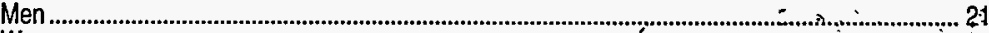

Women

OSHA-Recordable Relative Risk for All Diseases and Injuries by Occupation ' - . All OSHA-Recordable Diseases and Injuries by Occupational Categories ....................................... 22

OSHA-Recordable Relative Risk for Selected Disease and Injury Categories by Occupation ............. 22 Diseases of the Nervous System and Sense Organs ..........23

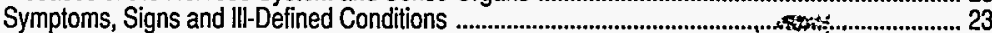

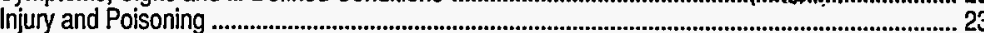

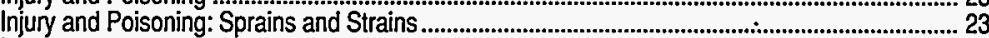
Iniury and Poisoning: Open Wounds .................. Injury and Poisoning: "Other" Injuries ................................................................................................. 24

Glossary and Statistical Notes inside back cover 


\section{Foreword}

The U.S. Department of Energy (DOE) is committed to assuring the health and safety of its workers through the development of epidemiologic surveillance activities. An epidemiologic surveillance program has been implemented at selected DOE sites during the past several years. This approach has been expanded to include surveillance of all medical conditions that result in an absence of 5 or more consecutive workdays, occupational injuries and illnesses, and deaths among active employees. This annual epidemiologic surveillance report provides the final summary of the 12-month period, January 1, 1994, through December 31, 1994, for the Idaho National Engineering Laboratory (INEL).

Caution is required when comparing this information with other DOE facilities. Interpretation of these data must take into account the occupational medicine program, health and safety practices, the composition of the work force, and potential occupational exposures unique to this facility; therefore, the data presented are pertinent only to INEL. Continuing surveillance and data examination may suggest emerging trends that change the preliminary interpretation of the data. Because of the change in contractors during 1994, comparison of this report with reports for previous years for this site should be done cautiously.
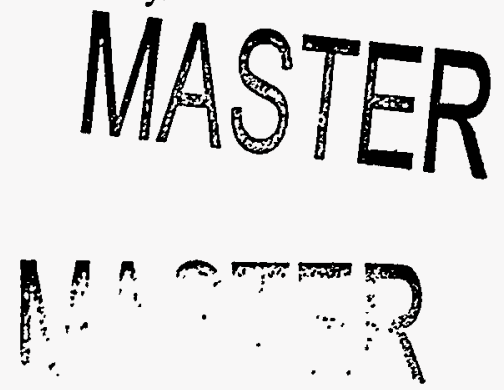

Plans for future annual reports include a discussion of important new findings and changes occurring since previous reports and the incorporation of information from the National Center for Health Statistics and the National Cancer Institute's Surveillance, Epidemiology, and End Results Program. This information will allow early recognition and investi- gation of possible work-related problems, as well as an analysis of trends over time. In addition, the results of epidemiologic surveillance will be combined with those of medical and exposure surveillance to form an integrated approach to worker health protection.

\section{INEL af a BInnce: 1994}

- INEL underwent a contractor consolidation in 1994 under Lockheed Idaho Technologies Company, resulting in an increase of 3,941 workers tracked by epidemiologic surveillance, a $52 \%$ increase from 1993.

- Reported rates of illness and injury declined in the INEL work force by about $50 \%$ from 1993, apparently due to the large increase in the number of workers being tracked following contractor consolidation. These workers were added to the roster of active workers tracked by epidemiologic surveillance, but they apparently generated few, if any, return to work clearances through the occupational medicine clinics that collect data for the surveillance program, thus reducing the apparent rates of illness and injury. About $4.4 \%$ of the INEL work force reported at least one absence of 5 or more days due to illness or injury.
- Excluding diagnoses related to pregnancy and delivery, the three highest diagnosis rates were once again associated with injuries, diseases of the musculoskeletal system, and respiratory illnesses.

- 1994 marks the first year for which OSHA-recordable injury and illness data were made available for epidemiologic surveillance. Women had a somewhat higher reported rate of OSHArecordable injuries and illnesses than did men. Service and crafts workers were at highest risk for OSHArecordable injuries.

- Overall, patterns of illness and injury observed in 1994 did not differ markedly from those seen in 1993 with the exception of a general reduction in reporting rates as noted above. 


\section{Iniroduction}

Epidemiologic surveillance at DOE

facilities consists of regular and systematic collection, analysis, and interpretation of data on absences due to illness and injury in the work force. Its purpose is to provide an early warning system for health problems occurring among employees at participating sites. Data are collected by coordinators at each site and submitted to the Epidemiologic Surveillance Data Center, located at the Oak Ridge Institute for Science and Education, where quality control procedures and analyses are carried out. Rates of absences and rates of diagnoses associated with absences are analyzed by occupation and other relevant variables. They may be compared with the disease experience of different groups within the DOE work force and with populations that do not work for DOE to identify disease patterns or clusters that may be associated with work activities.

In this annual report, the 1994 morbidity data for the Idaho National Engineering Laboratory are summarized. These analyses focus on absences of 5 or more consecutive workdays occurring among workers aged $17-85$ years. They are arranged in five sets of tables that present: 1) the distribution of the labor force by occupational category and pay status; 2) the absences per person, diagnoses per absence, and diagnosis rates for the whole work force; 3 ) diagnosis rates by type of disease or injury; 4) diagnosis rates by occupational category; and 5) relative risks for specific types of disease or injury by occupational category. In addition to this information, the report contains health events that are considered recordable by the Occupational Safety and Health Administration (OSHA). The analyses of the OSHA data are arranged like those involving absences of 5 or more consecutive workdays. OSHA-recordable events are those that occur on the job or involve fatalities (regardless of the time between the injury and death); lost workday cases other than fatalities; and nonfatal cases without lost workdays resulting in transfer to another job, termination of employment, medical treatment other than first aid, loss of consciousness, or restriction of work or motion. Also recordable are any diagnosed occupational health events reported to the employer that are neither fatal nor result in lost workdays. Deaths occurring among active workers are listed separately; they are not included in any tables. All rates presented in this report are age-adjusted (see glossary) and represent the number of diagnoses reported per 1,000 persons in 1 year.

Throughout this report, the symbol "NA" means "not available" or "not applicable." An empty cell in a table indicates that the value of the cell is zero or the value cannot be computed.

The tables show the results of analyses of diagnoses resulting from $a b$ sences. An absence is defined as a period of 5 or more consecutive workdays away from work due to some health problem such as an illness or injury. In tables presenting analyses of diagnoses, each diagnosis is counted because a diagnosis is for a specific illness or injury. A worker can have more than one diagnosis related to one absence from work. For example, a worker's single absence might involve both a back injury and pneumonia. Unlike analyses of absences, analyses of diagnoses focus on the rates of occurrence of specific types of disease and injury. Thus the worker with one absence in which he had a back injury and pneumonia would be counted twice in the analysis of diagnoses, because two separate diagnoses are recorded for this one absence.

The data included in this report are supplemental to, but do not replace those reported in other safety, industrial hygiene, and health physics reports prepared by DOE. There has been no attempt to validate diagnoses with medical records, pathology, or other laboratory reports. Also, there has been no attempt to validate occupational information reported by the site. For reporting purposes, occupational titles have been grouped into broad categories within which a great deal of diversity in tasks and exposures is likely to exist. Additional material outlining the methods used and explaining the diagnostic categories and frequently used terms can be found on the inside back cover. 


\section{DISCLAIMIRR.}

Portions of this document may be illegible in electronic image products. Images are produced from the best available original document. 


\section{Facility Overview}

The INEL is located in two primary areas: a remote 890 -square-mile desert site on the Snake River Plain and multiple locations in the city of Idaho Falls. Established in 1949 as the National Reactor Testing Station, it contains the largest concentration of nuclear reactors in the world.

Over the years, 52 reactors have been built at INEL. While the majority were phased out after completion of their research mission, several are currently operating.
In 1994, Lockheed Idaho Technologies Company became the sole contractor for INEL. Through 1993, various contractors for DOE-Idaho operated facilities at INEL's site, as well as administrative, scientific support, and nonnuclear research laboratories in Idaho Falls. Major contractors included EG\&G Idaho, Westinghouse Idaho Nuclear Company, and Babcock and Wilcox Idaho. In addition, Westinghouse Electric Corporation operated the

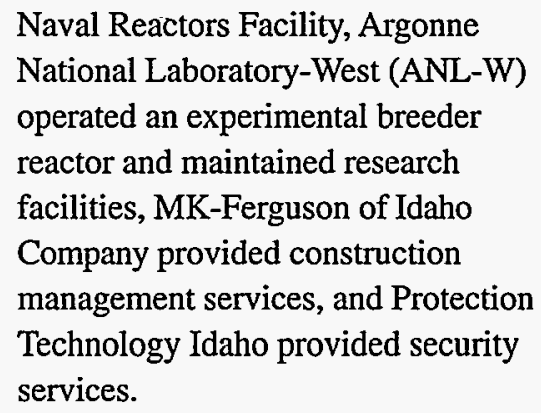


Labor Force by Oecupational Calegory and Salary Sialus, 1994

During 1994, there were $11,527 \mathrm{em}$ ployees (aged 17-85) identified by INEL as participants in epidemiologic surveillance. Seventy-four percent ( 8,533 workers) were men, and $26 \%$ (2,994 workers) were women. There were 115 employees excluded from this report because date of birth was not reported, and one person was excluded because no gender was reported. In addition, employees listed only on the first quarter roster $(2,052$ workers) were excluded due to missing job titles. None of these 2,052 workers had an absence of 5 or more consecutive workdays. Information regarding race of employees was not reported for the majority of the work force and, therefore, was not included in this report. Historically, the racial composition of the population was 92\% Caucasian and $8 \%$ African American, Asian, Hispanic, and Native American combined.

The composition of the labor force by occupational category and salary status is given in Table 1A; the change in labor force by year is depicted in Table 1B. The occupational categories used in these tables are based on the occupation and industry codes created by the Bureau of the Census in 1980. Because workers can change occupational category over the course of a year, workers were counted in the occupational category where they spent most of their time.

Workers with unknown job titles $(1,679)$ comprised a new occupational category not present last year. Because of the contractor change in 1994, only a portion of the employees had job title information available. The remainder were assigned a temporary occupational code. These workers were placed in the unknown occupational group.

Compared with 1993, the labor force in 1994 increased by $52 \%(3,941$ employees). The biggest increase was among workers in the service

\begin{tabular}{|c|c|c|c|}
\hline Occupational Category & $\begin{array}{l}\text { Number of } \\
\text { Workers in } \\
1994\end{array}$ & $\begin{array}{l}\text { Number of } \\
\text { Workers in } \\
1993\end{array}$ & $\begin{array}{l}\% \text { Change } \\
\text { from } \\
\text { Last Year }\end{array}$ \\
\hline Administrative & 3,018 & 1,971 & +53.1 \\
\hline$\cdots \cdot \cdots$ & $\ldots$ & .. & \\
\hline Professional & 2,722 & 2,769 & -1.7 \\
\hline $\begin{array}{llll}\cdots & . & \cdot & \ldots\end{array}$ & . & $\ldots$ & \\
\hline Technical & 1,659 & 1,444 & +14.9 \\
\hline . & &. & \\
\hline Service & 1,208 & 423 & +185.6 \\
\hline Crafts and Manual Labor & 701 & 664 & +5.6 \\
\hline Nuclear & 540 & 315 & +71.4 \\
\hline Unknown & 1,679 & 0 & NA \\
\hline TOTAL & 11,527 & 7,586 & +52.0 \\
\hline
\end{tabular}

Table 1A Labor Force by Occupational Category and Salary Status

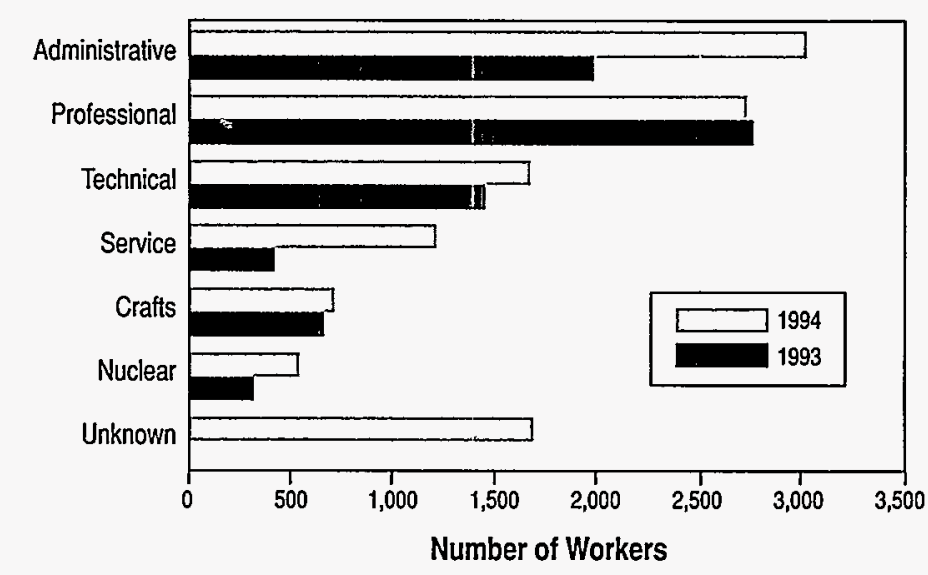

Table $1 B$.

Change in Labor Force by Year 


\section{Absences Among Work Force, 1994}

Absences per Person. In 1994, 507

INEL employees reported an absence of 5 or more consecutive workdays because of illness or injury. Fiftysix $(11 \%)$ of these workers had two or more absences. A total of $572 \mathrm{ab}-$ sences were reported by the employees (Table 2A).
: Diagnoses per Absence. A total of 720 diagnoses were associated with the 572 absences of 5 or more consecutive workdays. Multiple diagnoses were reported for 112 (20\%) absences (Table 2B).

\section{Diagnosis Rates for Absences. In} 1994, diagnoses noted for absences of 5 or more consecutive workdays

\begin{tabular}{|c|c|c|c|c|c|c|c|c|c|}
\hline \multirow{2}{*}{$\begin{array}{l}\text { Employee } \\
\text { Category }\end{array}$} & \multirow{2}{*}{$\begin{array}{l}\text { Number of } \\
\text { Workers } \\
\text { in } 1994\end{array}$} & \multicolumn{6}{|c|}{ Number of Absences } & \multirow{2}{*}{$\begin{array}{l}\text { Total } \\
\text { Persons } \\
\text { Absent at } \\
\text { Least Once. }\end{array}$} & \multirow{2}{*}{$\begin{array}{l}\text { Total } \\
\text { Number of } \\
\text { Absences }\end{array}$} \\
\hline & & 0 & 1 & 2 & 3 & 4 & 5 & & \\
\hline Men & 8,533 & 8,211 & 292 & 27 & 2 & 0 & 1 & 322 & 357 \\
\hline Women & 2,994 & 2,809 & 159 & 23 & 2 & 1 & 0 & 185 & 215 \\
\hline TOTAL & 11,527 & 11,020 & 451 & 50 & 4 & 1 & 1 & 507 & 572 \\
\hline
\end{tabular}

Table $2 A$.

Absences per

Person

\begin{tabular}{|c|c|c|c|c|c|c|}
\hline \multirow{2}{*}{$\begin{array}{l}\text { Employee } \\
\text { Category }\end{array}$} & \multicolumn{4}{|c|}{ Number of Diagnoses per Absence } & \multirow{2}{*}{$\begin{array}{l}\text { Total } \\
\text { Number of } \\
\text { Absences }\end{array}$} & \multirow{2}{*}{$\begin{array}{l}\text { Total } \\
\text { Number of } \\
\text { Diagnoses }\end{array}$} \\
\hline & 1 & 2 & 3 & 4 & & \\
\hline Men & 291 & 54 & 9 & 3 & 357 & 438 \\
\hline Women & 169 & 30 & 11 & 5 & 215 & 282 \\
\hline TOTAL & 460 & 84 & 20 & 8 & 572 & 720 \\
\hline
\end{tabular}

Table $2 B$.

Diagnoses per

Absence

\begin{tabular}{|l|c|c|c|c|c|c|}
\hline $\begin{array}{l}\text { Employee } \\
\text { Category }\end{array}$ & $\begin{array}{l}\text { Number of } \\
\text { Workers } \\
\text { in 1994 }\end{array}$ & $\begin{array}{l}\text { Number of } \\
\text { Diagnosest }\end{array}$ & $\begin{array}{l}\text { Crude } \\
\text { Rate per } \\
1,000\end{array}$ & $\begin{array}{l}\text { Age- } \\
\text { Adjusted } \\
\text { Rate per } \\
1,000^{*}\end{array}$ & $\begin{array}{l}\text { Lower 95\% } \\
\text { Confidence } \\
\text { Limit per } \\
1,000\end{array}$ & $\begin{array}{l}\text { Upper 95\% } \\
\text { Confidence } \\
\text { Limit per } \\
1,000\end{array}$ \\
\hline Men & $\begin{array}{c}8,533 \\
\ldots .\end{array}$ & 438 & 51.3 & 48.8 & 43.9 & 54.1 \\
Women & 2,994 & 282 & 94.2 & 98.3 & 86.5 & 111.7 \\
\hline TOTAL & 11,527 & 720 & 62.5 & 63.5 & 58.6 & 68.8 \\
\hline
\end{tabular}

Table 2C.

Diagnosis Rates for Absences

$\dagger$ Includes all diagnoses reported with an absence of 5 or more days, including absences for pregnancy and delivery.

- Standardized to age distribution of 1970 U.S. population. 


\section{Diseases and Injuries by Dingnostic Calegory, 1994}

The age-adjusted diagnosis rate for each diagnostic category is given for all workers in Table 3 . Tables 4 and 5 show diagnosis rates by gender to further describe the disease and injury patterns in the work force. Diagnoses associated with pregnancy, labor, and delivery are described in Table 6 .

For all workers, the three diagnostic categories with the highest rates excluding pregnancy and childbirth (Table 3 ) were injury and poisoning (9.9 per 1,000$)$, diseases of the respiratory system $(8.9$ per 1,000$)$, and diseases of the musculoskeletal system $(8.1$ per 1,000$)$. Together these three categories accounted for $45 \%$ of all diagnoses.

Men. The diagnostic category with the highest rate among men (Table 4) was injury and poisoning ( $9.6 \mathrm{per}$ 1,000 ), with 87 diagnoses reported for 77 men. Within this category, two subcategories had relatively high numbers of diagnoses. Sprains and strains accounted for $28 \%$ of these diagnoses with 24 diagnoses among 22 men. Of these diagnoses, 12 were sprains and strains of the back, 6 of the lower extremities, and 6 of the upper extremities. Two men had multiple diagnoses. "Other" injuries accounted for $37 \%$ of the injury and poisoning diagnoses, with 32 diagnoses among $32 \mathrm{men}$. These diagnoses included 14 unspecified injuries; 5 complications of body systems; 4 adverse drug reactions; 3 contusions; 2 late effects of injuries; 1 each for heat stress, post operative infection, a blister on the foot/toe, and a foreign body on the eye.
The second highest rate, accounting for $16 \%$ of the total diagnoses, was diseases of the digestive system (7.4 per 1,000), with 68 diagnoses reported among 63 men. Thirty diagnoses were related to hernias; 11 to gall bladder disease; 7 to other diseases of the intestines and peritoneum; 5 to appendicitis; 5 to diseases of the esophagus, stomach, and duodenum; 4 to diseases of the oral cavity, salivary glands, and jaws; 3 to liver disorders; 2 to noninfectious gastroenteritis and colitis; and 1 to chronic pancreatitis. Five men had multiple diagnoses.

Diseases of the musculoskeletal system $(6.3$ per 1,000$)$ ranked third, with 60 diagnoses reported for 53 men. Twenty-six diagnoses were related to dorsopathies (spinal disorders), 18 to arthritis and joint disorders, 15 to rheumatism (excluding the back), and 1 to a deformity of the toe. Five men had multiple diagnoses.

Fifteen cancer diagnoses were reported among $11 \mathrm{men}$ in 1994. Five men had a total of six diagnoses of prostate cancer. Two men had a total of two diagnoses for bladder cancer; and one man had four diagnoses for multiple myeloma. One man each had a diagnosis for Hodgkin's disease, malignant melanoma of the skin, and pancreatic cancer.

Women. The diagnostic category with the highest rate among women (Table 5) was diseases of the respiratory system (19.4 per 1,000), with 55 diagnoses reported among 47 women.
This accounted for $20 \%$ of all diagnoses among women. Twenty-three diagnoses were related to upper respiratory diseases, 22 to pneumonia/ bronchitis, 9 to chronic respiratory conditions, and 1 to pleurisy. Seven women had multiple diagnoses.

The second highest rate, accounting for $12 \%$ of the total diagnoses, was for diseases of the musculoskeletal system $(13.5$ per 1,000$)$, with 35 diagnoses among 29 women. Of these diagnoses, 13 were related to rheumatism (excluding the back), 9 to dorsopathies (spinal disorders), 8 to arthritis and joint disorders, 2 to bone and cartilage disorders, 2 to acquired toe deformities, and 1 to bone inflammation. Four women had multiple diagnoses.

Injury and poisoning $(12.4$ per 1,000$)$ ranked third, with 39 diagnoses reported for 34 women. Within this category, "other" injuries accounted for $54 \%$ of the injury and poisoning diagnoses, with 21 diagnoses among 20 women. These 21 diagnoses included 8 unspecified injuries, 7 complications of surgical and medical care, 3 contusions, 2 late effects of injuries, and 1 spinal cord injury. One woman had multiple diagnoses.

Three cancer diagnoses were reported for two women in 1994. All three diagnoses were for breast cancer. 


\begin{tabular}{|c|c|c|c|c|c|}
\hline Category of Dlagnoses & ICD9-CM Code & $\begin{array}{l}\text { Number of } \\
\text { Diagnosest }\end{array}$ & $\begin{array}{l}\text { Age- } \\
\text { Adjusted } \\
\text { Rate per } \\
1,000^{*}\end{array}$ & $\begin{array}{l}\text { Lower } 95 \% \\
\text { Confidence } \\
\text { Limit per } \\
1,000\end{array}$ & $\begin{array}{l}\text { Upper } 95 \% \\
\text { Confidence } \\
\text { Limit per } \\
1,000\end{array}$ \\
\hline Infections and parasitic diseases & 001-139. & 26 & 2.4 & 1.5 & 3.6 \\
\hline Malignant neoplasms & $140-208,230-234$ & 18 & 1.7 & 1.1 & 2.8 \\
\hline - Digeslive organs & $150-159$ & 1 & 0.1 & 0.0 & 0.9 \\
\hline - Respiratory system & $160-165$ & 0 & & & \\
\hline - Breast & $174-175$ & 3 & 0.2 & 0.1 & 0.7 \\
\hline - Genitourinary & $179-189$ & 8 & 0.8 & 0.4 & 1.7 \\
\hline - Nervous system & $191-192$ & 0 & & & \\
\hline - Leukemia, lymphoma & $200-208$ & 5 & 0.4 & 0.2 & 1.1 \\
\hline Benign neoplasms and other & $210-229,235-239$ & 10 & 0.9 & 0.4 & 1.8 \\
\hline Endocrine and metabolic diseases & $240-279$ & 13 & 1.1 & 0.6 & 1.9 \\
\hline Blood and blood-forming organs & $280-289$ & 1 & 0.1 & 0.0 & 0.4 \\
\hline Mental disorders & $290-319$ & 16 & 1.0 & 0.6 & 1.7 \\
\hline - Alcoholism & 303 & 2 & 0.2 & 0.0 & 0.6 \\
\hline - Drug abuse & $304-305$ & 0 & & & \\
\hline Nervous system and sense organs & $320-389$ & 44 & 3.8 & 2.8 & 5.3 \\
\hline Circulalory system & $390-459$ & 47 & 4.4 & 3.3 & 6.0 \\
\hline - Hypertension & 401 & 2 & 0.2 & 0.1 & 0.9 \\
\hline - Acute myocardial infarction & 410 & 6 & 0.6 & 0.3 & 1.4 \\
\hline - Ischemic disease, not M.I. & $411-414,429.2$ & 18 & 1.7 & 1.0 & 2.7 \\
\hline - Cerebrovascular disease & $430-438$ & 4 & 0.3 & 0.1 & 0.9 \\
\hline Respiratory system & $460-519$ & 103 & 8.9 & 7.2 & 11.0 \\
\hline - Upper respiratory & $460-465,470-478$ & 48 & 3.9 & 2.9 & 5.3 \\
\hline - Pneumonia/bronchitis & $466,480-487$ & 33 & 3.2 & 2.2 & 4.6 \\
\hline - Chronic respiratory conditions & $490-496$ & 20 & 1.8 & 1.1 & 2.8 \\
\hline Digestive system & $520-579$ & 92 & 7.9 & 6.3 & 9.8 \\
\hline - Hernias & $550-553$ & 32 & 2.8 & 2.0 & 4.0 \\
\hline - Gall bladder disease & $574-575$ & 20 & 1.7 & 1.1 & 2.7 \\
\hline Genitourinary system & $580-629$ & 55 & 5.2 & 3.9 & 7.0 \\
\hline - Benign prostatic hypertrophy & 600 & 5 & 0.5 & 0.2 & 1.2 \\
\hline - Endometriosis & 617 & 3 & 0.3 & 0.1 & 1.1 \\
\hline - Ovarian cysts & $620.0-620.2$ & 5 & 0.7 & 0.3 & 1.8 \\
\hline - Female genilal painbleeding & $625-626$ & 4 & 0.4 & 0.1 & 1.1 \\
\hline Pregnancy and childbirth 1 & $630-676$ & 30 & 4.5 & 3.1 & 6.6 \\
\hline Skin and subcutaneous tissue & $680-709$ & 4 & 0.3 & 0.1 & 0.8 \\
\hline Musculoskeletal system & $710-739$ & 95 & 8.1 & 6.5 & 10.0 \\
\hline - Dorsopathies & $720-724$ & 35 & 2.9 & 2.0 & 4.1 \\
\hline Congenital anomalies & $740-759$ & 1 & 0.1 & 0.0 & 0.4 \\
\hline Certain perinatal conditions & $760-779$ & 0 & & & \\
\hline Symptoms, signs, and ill-defined conditions & $780-799$ & 25 & 2.0 & 1.3 & 3.1 \\
\hline Injury and poisoning & $800-999$ & 126 & 9.9 & 8.2 & 12.0 \\
\hline - Fractures, all sites & $800-829$ & 22 & 1.9 & 1.2 & 3.0 \\
\hline - Dislocations & $830-839$ & 11 & 0.8 & 0.4 & 1.4 \\
\hline - Sprains and strains & $840-848$ & 30 & 2.6 & 1.8 & 3.8 \\
\hline - Intracranial injuries & $850-854$ & 5 & 0.4 & 0.1 & 0.9 \\
\hline - Internal injuries & $860-869$ & 2 & 0.1 & 0.0 & 0.5 \\
\hline - Open wounds & $870-897$ & 3 & 0.2 & 0.1 & 0.8 \\
\hline - Other injuries & 900.999 & 53 & 4.0 & 3.0 & 5.3 \\
\hline Health stalus/heallh service contract & V01-V82 & 14 & 1.3 & 0.7 & 2.3 \\
\hline - Family history of health problems & V10-V19 & 2 & 0.2 & 0.0 & 0.6 \\
\hline - Circumstances related to reproduction/development & V20-V28 & 5 & 0.6 & 0.2 & 1.5 \\
\hline - Specific procedure/aftercare & V50-V59 & 5 & 0.4 & 0.2 & 1.2 \\
\hline Total minus pregnancles & & 690 & 59.0 & 54.4 & 64.0 \\
\hline TOTAL & & 720 & 63.5 & 58.6 & 68.8 \\
\hline
\end{tabular}

Table 3.

Diseases and

Injuries by

Diagnostic

Category - Men

and Women

- Digestive organs

Respiratory system

- Genitourinary

- Nervous system

Endocrine and metabolic diseases

Blood and blood-forming organs

ervous system and sense organs

spiratory system

- Pneumoniabronchitis

Gall bladder disease

- Endometriosis

- Ovarian cysts

- Female genital paindleeding

Skin and subcutaneous tissue

Musculoskeletal system

Certain perinatal conditions

mploms, signs, and ill-defined condition

- Fractures, all sites

- Dislocations

Sprains and strains

Intracranial injuries

- Open wounds

- Other injuries

and Women

tIndudes all diagnoses reported with an absence of 5 or more days.

Standardized to age distribution of 1970 U.S. population.

10 Only women aged $18-45$ were induded in the calculation of the rates for these diagnostic categories. 


\begin{tabular}{|c|c|c|c|c|c|}
\hline Category of Diagnoses & ICD9-CM Code & $\begin{array}{l}\text { Number of } \\
\text { Diagnosest }\end{array}$ & $\begin{array}{l}\text { Age- } \\
\text { Adjusted } \\
\text { Rate per } \\
1,000^{\star}\end{array}$ & $\begin{array}{l}\text { Lower } 95 \% \\
\text { Confidence } \\
\text { Limit per } \\
1,000\end{array}$ & $\begin{array}{l}\text { Upper } 95 \% \\
\text { Confidence } \\
\text { Limit per } \\
1,000\end{array}$ \\
\hline Infections and parasitic diseases & $001-139$ & 17 & 2.2. & 1.2 & 4.0 \\
\hline Malignant neoplasms & $140-208,230-234$ & 15 & 1.8 & 1.1 & 3.0 \\
\hline - Digestive organs & $150-159$ & 1 & 0.1 & 0.0 & 1.0 \\
\hline - Respiratory system & $160-165$ & 0 & & & \\
\hline - Breast & $174-175$ & 0 & & & \\
\hline - Genitourinary & $179-189$ & 8 & 1.0 & 0.5 & 2.0 \\
\hline - Nervous system & $191-192$ & 0 & & & \\
\hline - Leukemia, lymphoma & $200-208$ & 5 & 0.5 & 0.2 & 1.3 \\
\hline Benign neoplasms and other & $210-229,235-239$ & 6 & 0.5 & 0.2 & 1.2 \\
\hline Endocrine and metabolic diseases $\quad \ldots$ & $240-279$ & 9 & 0.9 & 0.5 & 1.8 \\
\hline Blood and blood-forming organs & $280-289$ & 0 & & & \\
\hline Mental disorders & $290-319$ & 7 & 0.6 & 0.3 & 1.3 \\
\hline - Alcoholism & 303 & 1 & 0.1 & 0.0 & 0.8 \\
\hline - Drug abuse & $304-305$ & 0 & & & \\
\hline Nervous system and sense organs & $320-389$ & 26 & 2.5 & 1.7 & 3.7 \\
\hline Circulatory system & $390-459$ & 41 & 5.0 & 3.6 & 7.0 \\
\hline - Hypertension & 401 & 2 & 0.3 & 0.1 & 1.0 \\
\hline - Acute myocardial infarction & 410 & 5 & 0.6 & 0.3 & 1.5 \\
\hline - Ischemic disease, not M.I. & $411-414,429.2$ & 16 & 1.8 & 1.1 & 3.0 \\
\hline - Cerebrovascular disease & $430-438$ & 4 & 0.4 & 0.2 & 1.1 \\
\hline Respiratory system & $460-519$ & 48 & 5.5 & 4.0 & 7.7 \\
\hline - Upper respiratory & $460-465,470-478$ & 25 & 2.7 & 1.7 & 4.3 \\
\hline - Pneumonia/bronchitis & $466,480-487$ & 11 & 1.4 & 0.7 & 2,7 \\
\hline - Chronic respiratory conditions & $490-496$ & 11 & 1.4 & 0.7 & 2.7 \\
\hline Digestive system & $520-579$ & 68 & 7.4 & 5.7 & 9.5 \\
\hline - Hernias & $550-553$ & 30 & 3.4 & 2.3 & 5.0 \\
\hline - Gall bladder disease & $574-575$ & 11 & 1.2 & 0.6 & 2.1 \\
\hline Genitourinary system & $580-629$ & 26 & 3.3 & 2.1 & 5.0 \\
\hline - Benign prostatic hypertrophy & 600 & 5 & 0.6 & 0.2 & 1.4 \\
\hline - Endometriosis & 617 & NA & & & \\
\hline - Ovarian cysts & $620.0-620.2$ & NA & & & \\
\hline - Female genital pain/bleeding & $625-626$ & NA & & & \\
\hline Pregnancy and childbirth & $630-676$ & $\mathrm{NA}$ & & & \\
\hline Skin and subcutaneous tissue & $680-709$ & 3 & 0.2 & 0.1 & 0.8 \\
\hline Musculoskeletal system & $710-739$ & 60 & 6.3 & 4.8 & 8.3 \\
\hline - Dorsopathies & $720-724$ & 26 & 2.6 & 1.8 & 3.9 \\
\hline Congenital anomalies. & $740-759$ & 1 & 0.1 . & 0.0 & 0.6 \\
\hline Certain perinatal conditions & $760-779$ & 0 & & & \\
\hline Symptoms, signs, and ill-defined conditions & $780-799$ & 13 & 1.3 & 0.8 & 2.3 \\
\hline Injury and poisoning & $800-999$ & 87 & 9.6 & 7.5 & 12.2 \\
\hline - Fractures, all sites & $800-829$ & 17 & 2.3 & 1.3 & 4.0 \\
\hline - Dislocations & $830-839$ & 7 & 0.6 & 0.3 & 1.4 \\
\hline - Sprains and strains & $840-848$ & 24 & 3.0 & 1.9 & 4.9 \\
\hline - Intracranial injuries & $850-854$ & 3 & 0.3 & 0.1 & 1.0 \\
\hline - Internal injuries & $860-869$ & 1 & 0.1 & 0.0 & 0.6 \\
\hline - Open wounds & $870-897$ & 3 & 0.3 & 0.1 & 1.0 \\
\hline - Other injuries & $900-999$ & 32. & 2.9 & 2.1 & 4.2 \\
\hline Health status/health service contract & V01-V82 & 11 & 1.4 & 0.7 & 3.0 \\
\hline - Family history of health problems & $V 10-V 19$ & 2 & 0.2 & 0.0 & 0.8 \\
\hline - Circumstances related to reproductionddevelopment & V20-V28 & 4 & 0.6 & 0.2 & 1.9 \\
\hline - Specific procedure/aftercare & V50-V59 & 4 & 0.6 & 0.2 & 1.9 \\
\hline TOTAL & & 438 & 48.8 & 43.9 & 54.1 \\
\hline
\end{tabular}

Table 4.

Diseases

and Injuries

by Diagnostic

Category - Men

- Respiratory system

- Breast

ental disorders

- Alcoholism

- Drug abuse

vous system and sense organ

- Acute myocardial infarction

- Ischemic disease, not M.I.

- Cerebrovascular disease

- Upper respirator

- Pneumonia/bronchitis

- Chronic respiratory conditions

- Benign prostatic hypertrophy

egnancy and childbirth

issue

Certain perinatal conditions

- Dislocations

- Sprains and strains

- Intracranial injuries

ernal injuries

- Open wounds OTA

fIncludes all diagnoses reported with an absence of 5 or more days. - Standarcized to age distribution of 1970 U.S. population. 


\begin{tabular}{|c|c|c|c|c|c|}
\hline Category of Dlagnoses & ICD9-CM Code & $\begin{array}{l}\text { Number of } \\
\text { Diagnosest }\end{array}$ & $\begin{array}{l}\text { Age- } \\
\text { Adjusted } \\
\text { Rate per } \\
1,000^{*}\end{array}$ & $\begin{array}{l}\text { Lower } 95 \% \\
\text { Confidence } \\
\text { Limit per } \\
1,000\end{array}$ & $\begin{array}{l}\text { Upper } 95 \% \\
\text { Confidence } \\
\text { Limit per } \\
1,000\end{array}$ \\
\hline Infections and parasitic diseases & $001-139$ & 9 & 3.0 & 1.5 & 6.0 \\
\hline Malignant neoplasms & $140-208,230-234$ & 3 & 0.9 & 0.3 & 3.1 \\
\hline - Digestive organs & $150-159$ & 0 & & & \\
\hline - Respiratory system & $160-165$ & 0 & & & \\
\hline - Breast & $174-175$ & 3 & 0.9 & 0.3 & 3.1 \\
\hline - Genitourinary & $179-189$ & 0 & & & \\
\hline - Nervous system & $191-192$ & 0 & & & \\
\hline - Leukemia, lymphoma & $200-208$ & 0 & & & \\
\hline Benign neoplasms and other & $210-229,235-239$ & 4 & 1.4 & 0.5 & 3.7 \\
\hline Endocrine and metabolic diseases & $240-279$ & 4 & 1.0 & 0.4 & 2.9 \\
\hline Blood and blood-forming organs & $280-289$ & 1 & 0.3 & 0.0 & 2.0 \\
\hline Mental disorders & $290-319$ & 9 & 2.4 & 1.2 & 4.7 \\
\hline - Alcoholism & 303 & 1 & 0.2 & 0.0 & 1.5 \\
\hline - Drug abuse & $304-305$ & 0 & & & \\
\hline Nervous system and sense organs & $320-389$ & 18 & 7.4 & 4.4 & 12.3 \\
\hline Circulatory system & $390-459$ & 6 & 2.4 & 1.0 & 5.5 \\
\hline - Hypertension & 401 & 0 & & & \\
\hline - Acute myocardial infarction & 410 & 1 & 0.5 & 0.1 & 3.4 \\
\hline - Ischemic disease, not M.I. & $411-414,429.2$ & 2 & 1.0 & 0.2 & 3.8 \\
\hline - Cerebrovascular disease & $430-438$ & 0 & & & \\
\hline Respiratory system & $460-519$ & 55 & 19.4 & 14.4 & 26.1 \\
\hline - Upper respiratony & $460-465,470-478$ & 23 & 7.9 & 5.1 & 12.2 \\
\hline - Pneumonia/bronchitis & $466,480-487$ & 22 & 8.4 & 5.1 & 13.9 \\
\hline - Chronic respiratory conditions & $490-496$ & 9 & 2.8 & 1.4 & 5.5 \\
\hline Digestive system & $520-579$ & 24 & 7.9 & 5.2 & 11.9 \\
\hline - Hernias & $550-553$ & 2 & 0.7 & 0.2 & 3.0 \\
\hline - Gall bladder disease & $574-575$ & 9 & 3.2 & 1.6 & 6.3 \\
\hline Genitourinary system & $580-629$ & 29 & 10.2 & 6.8 & 15.3 \\
\hline - Benign prostatic hypentrophy & 600 & NA & & & \\
\hline - Endometriosis & 617 & 3 & 0.9 & 0.3 & 2.9 \\
\hline - Ovarian cysts & $620.0-620.2$ & 5 & 1.8 & 0.7 & 4.4 \\
\hline - Female genital pain/bleeding & $625-626$ & 4 & 1.2 & 0.4 & 3.2 \\
\hline Pregnancy and childbirth' & $630-676$ & 30 & 10.8 & 7.5 & 15.6 \\
\hline Skin and subcutaneous tissue & $680-709$ & 1 & 0.5 & 0.1 & 3.4 \\
\hline Musculoskeletal system & $710-739$ & 35 & 13.5 & 9.4 & 19.3 \\
\hline - Dorsopathies & $720-724$ & 9 & 2.6 . & 1.3 & 5.3 \\
\hline Congenital anomalies & $740-759$ & 0 & & & \\
\hline Certain perinatal conditions & $760 \cdot 779$ & 0 & & & \\
\hline Symptoms, signs, and ill-defined conditions & $780-799$ & 12 & 4.0 & 2.2 & 7.2 \\
\hline Injury and poisoning & $800-999$ & 39 & 12.4 & 8.7 & 17.7 \\
\hline - Fractures, all sites & $800-829$ & 5 & 1.7 & 0.6 & 4.2 \\
\hline - Dislocations & $830-839$ & 4 & 1.1 & 0.4 & 3.2 \\
\hline - Sprains and strains & $840-848$ & 6 & 2.2 & 0.8 & 6.5 \\
\hline - Intracranial injuries & $850-854$ & 2 & 0.4 & 0.1 & 1.7 \\
\hline - Internal injuries & $860-869$ & 1. & -. 0.2 & 0.0 & 1.5 \\
\hline - Open wounds & $870-897$ & 0 & $r$ & & \\
\hline - Other injuries & _. $900-999$ & 21. & $6.8^{\circ}$ & 4.3 & 10.6 \\
\hline Health status/health service contract & V01-v82 & 3 & 0.9 & 0.3 & 2.9 \\
\hline - Family history of health problems & $V_{10} \cdot V_{19}$ & 0 & & & \\
\hline - Circumstances related to reproduction/development & V20-V28 & 1 & 0.4 & 0.1 & 2.9 \\
\hline - Specific procedure/aftercare & V50-V59 & 1 & 0.3 & 0.0 & 2.0 \\
\hline Tolal minus pregnancies & & 252 & 87.5 & 76.4 & 100.2 \\
\hline TOTAL & & 282 & 98.3 & 86.5 & 111.7 \\
\hline
\end{tabular}

Table 5.

Diseases

and Injuries

by Diagnostic

Category - Women

- Digestive organs

- Genitourinary

- Nervous system

Benign neoplasms and othe

Endocrine and metabolic diseases

Alcoholism

Circulatory system

Hypertension

-

- Ischemic disease not M.

- Gall bladder disease

enitourinary system

Benign prostatic hypertrophy

- Female genital pain/bleeding

Pregnancy and childbirth

subcutaneous tissue

culoskeletal system

- Dorsopathies

Congenital anomalies

Symptoms, signs, and ill-defined conditions

ury and poisoning

- Fractures, all sites

- Sprains and strains

- Intracranial injuries

(enal injuries

- Open wounds

- Other injuries

alth statushealth service contract

- Family hision ot health problems

- Circumstances related to reproduction/development

tndudes all diagnoses reported with an absence of 5 or more days.

- Standardized to age distribution of 1970 U.S. population.

10 only women aged $18-45$ were induded in the calculation of the rates for these diagnostic categories. 
Diagnoses Associnted with Pregnaney, Labor, and Delivery

During 1994, 30 pregnancy-related diagnoses were reported among 29 women (Table 6). One woman had multiple diagnoses. There were four diagnoses for complications related to pregnancy; four for complications of labor, delivery, and puerperium; and two for other indications for care in pregnancy, labor, and delivery. Twenty women had normal deliveries.

\section{Diagnoses by Oceupalional Category, 1994}

During 1994, the age-adjusted diagnosis rate for all employees (Table 7) was 63.5 per 1,000 persons. Service workers had the highest diagnosis rate $(133.9$ per 1,000$)$, with 159 diagnoses reported for 104 workers. Administrative workers had the second highest diagnosis rate $(81.0$ per 1,000), with 222 diagnoses reported among 148 persons. Technical workers ranked third, with 119 diagnoses reported for 84 workers (72.6 per 1,000 ). Workers in the unknown category had the lowest rate (7.1 per 1,000 workers), with 13 diagnoses among 9 workers.

\section{Men. The diagnosis rate among} men was 48.8 per 1,000 . Service workers had the highest rate (109.8 per 1,000 ), with 105 diagnoses reported for 73 men. The second highest rate was among the nuclear workers (72.9 per 1,000$)$, with 28 diagnoses reported among 23 men. Crafts and manual laborers ranked third, with 43 diagnoses reported among 35 men $(67.7$ per 1,000$)$. Workers in the unknown category had the lowest rate $(1.7$ per 1,000$)$, with two diagnoses for two men.
Women. The diagnosis rate among women (Table 9) was 98.3 per 1,000. Service workers had the highest rate (213.1 per 1,000), with 54 diagnoses reported among 31 women. The second highest rate was among the crafts and manual laborers (131.9 per 1,000$)$, with eight diagnoses reported among three women. Administrative workers ranked third, with 146 diagnoses reported among 96 women (119.2 per 1,000). Workers in the unknown category had the lowest rate $(21.1$ per 1,000$)$, with 11 diagnoses among 7 women. The women had higher diagnosis rates than the men; this suggests a greater tendency among women to report injury or illness.

\begin{tabular}{|c|c|c|c|c|c|}
\hline Category of Diagnoses & ICD9-CM Code & $\begin{array}{l}\text { Number of } \\
\text { Diagnosest }\end{array}$ & $\begin{array}{l}\text { Age- } \\
\text { Adjusted } \\
\text { Rate per } \\
1,000^{\star}\end{array}$ & $\begin{array}{l}\text { Lower } 95 \% \\
\text { Confidence } \\
\text { Limit per } \\
1,000\end{array}$ & $\begin{array}{l}\text { Upper } 95 \% \\
\text { Confidence } \\
\text { Limit per } \\
1,000\end{array}$ \\
\hline $\begin{array}{l}\text { Ectopic and Molar } \\
\text { Pregnancy/Abortive Outcome }\end{array}$ & $630-639$ & 0 & & & \\
\hline Complications Related to Pregnancy & $640-648$ & 4 & 1.5 & 0.5 & 4.0 \\
\hline Normal Delivery & 650 & 20 & 7.1 & 4.5 & 11.2 \\
\hline $\begin{array}{l}\text { Other Indications for Care in } \\
\text { Pregnancy, Labor, and Deliverył }\end{array}$ & $651-659$ & 2 & 0.8 & 0.2 & 3.3 \\
\hline $\begin{array}{l}\text { Complications of Labor, Delivery, } \\
\text { and Puerperium }\end{array}$ & $660-676$ & 4 & 1.5 & 0.5 & 4.0 \\
\hline TOTAL & & 30 & 10.9 & 7.5 & 15.8 \\
\hline
\end{tabular}

Table 6.

Diagnoses

Associated with Pregnancy, Labor, and Delivery

† Includes all diagnoses reported with an absence of 5 or more days.

- Only women aged 18-45 were included in the calculation of the rates for these diagnostic categories. ¥ Includes delivery by cesarian section and multiple births. 


\begin{tabular}{|l|c|c|c|c|c|}
\hline & $\begin{array}{l}\text { Number of } \\
\text { Workers } \\
\text { in 1994 }\end{array}$ & $\begin{array}{l}\text { Number of } \\
\text { Diagnoses }\end{array}$ & $\begin{array}{l}\text { Age- } \\
\text { Adjusted } \\
\text { Rate per 1,000* }\end{array}$ & $\begin{array}{l}\text { Lower 95\% } \\
\text { Confidence } \\
\text { Limit per } \\
1,000\end{array}$ & $\begin{array}{l}\text { Upper 95\% } \\
\text { Confidence } \\
\text { Limit per } \\
1,000\end{array}$ \\
\hline $\begin{array}{l}\text { Administrative } \\
\text { Professional }\end{array}$ & 3,018 & 222 & 81.0 & 69.5 & 94.4 \\
\hdashline Technical & 2,722 & 120 & 46.0 & 37.5 & 56.4 \\
\hdashline Service & 1,659 & 119 & 72.6 & 59.7 & 88.5 \\
\hdashline Crafts and Manual Labor & 1,208 & 159 & 133.9 & 112.2 & 159.9 \\
\hdashline Nuclear & 701 & 51 & 68.8 & 50.2 & 94.3 \\
\hdashline Unknown & 540 & 36 & 71.3 & 48.6 & 104.6 \\
\hline TOTAL & 1,679 & 13 & 7.1 & 4.1 & 12.4 \\
\hline
\end{tabular}

Table 7.

Diagnoses by

Occupational

Category - Men

and Women

\begin{tabular}{|l|c|c|c|c|c|}
\hline & $\begin{array}{l}\text { Number of } \\
\text { Workers } \\
\text { in } 1994\end{array}$ & $\begin{array}{l}\text { Number of } \\
\text { Diagnosest }\end{array}$ & $\begin{array}{l}\text { Age- } \\
\text { Adjusted } \\
\text { Rate per 1,000* }\end{array}$ & $\begin{array}{l}\text { Lower 95\% } \\
\text { Confidence } \\
\text { Limit per } \\
1,000\end{array}$ & $\begin{array}{l}\text { Upper 95\% } \\
\text { Confidence } \\
\text { Limit per } \\
1,000\end{array}$ \\
\hline Administrative & 1,774 & 76 & 39.4 & 29.0 & 53.4 \\
Professional & 2,268 & 103 & 41.8 & .33 .5 & 52.1 \\
\hdashline Technical & 1,252 & 81 & 61.4 & 48.5 & 77.7 \\
\hdashline Service & 948 & 105 & 109.8 & 87.8 & 137.3 \\
\hdashline Crafis and Manual Labor & 646 & 43 & 67.7 & 47.6 & 96.2 \\
\hdashline Nuclear & 460 & 28 & 72.9 & 46.4 & 114.5 \\
\hline Unknown & 1,185 & 2 & 1.7 & 0.4 & 6.9 \\
\hline TOTAL & 8,533 & 438 & 48.8 & 43.9 & 54.1 \\
\hline
\end{tabular}

\begin{tabular}{|l|c|c|c|c|c|}
\hline & $\begin{array}{l}\text { Number of } \\
\text { Workers } \\
\text { in 1994 }\end{array}$ & $\begin{array}{l}\text { Number of } \\
\text { Diagnoses }\end{array}$ & $\begin{array}{l}\text { Age- } \\
\text { Adjusted } \\
\text { Rate per 1,000* }\end{array}$ & $\begin{array}{l}\text { Lower 95\% } \\
\text { Confidence } \\
\text { Limit per } \\
\mathbf{1 , 0 0 0}\end{array}$ & $\begin{array}{l}\text { Upper 95\% } \\
\text { Confidence } \\
\text { Limit per } \\
\mathbf{1 , 0 0 0}\end{array}$ \\
\hline $\begin{array}{l}\text { Odministrative } \\
\text { Professional }\end{array}$ & 1,244 & 146 & 119.2 & 99.8 & 142.4 \\
\hdashline Technical & 454 & 17 & 39.4 & 22.8 & 68.3 \\
\hdashline Senvice & 407 & 38 & 91.3 & 64.7 & 129.0 \\
\hdashline Crafts and Manual Labor & 260 & 54 & 213.1 & 159.9 & 284.0 \\
\hdashline Nuclear & 55 & 8 & 131.9 & 64.5 & 269.7 \\
\hline Unknown & 80 & 8 & 78.1 & 37.7 & 161.8 \\
\hline TOTAL & 494 & 11 & 21.1 & 11.3 & 39.4 \\
\hline
\end{tabular}

Table 8.

Diagnoses by

Occupational

Category - Men

Table 9.

Diagnoses by

Occupational

Category -

Women

† Includes all diagnoses reported with an absence of 5 or more days, including absences for pregnancy and childbirth.

- Standardized to age distribution of 1970 U.S. population. 


\section{Deuihs Among Active Workers, 1994}

There were four deaths reported among active workers in 1994. The causes of death were an accident at home, a gunshot wound, a brain aneurysm, and natural causes.

\section{Relative Risk for All Disenses and Injuries by Occupution}

In Table 10, the risk of one or more absences associated with selected diagnostic categories for specific occupational categories is compared with all other occupational categories in the INEL work force. This comparison takes into account the possible confounding effects of age and gender. In contrast to the previous series of tables, these analyses examine the risk of a worker having one or more absences for 5 or more consecutive workdays during 1994. This was done to minimize the problem associated with one person having multiple absences for the same condition

Throughout this report, various tables and discussions refer to rates of illness or injury. Rates in this report reflect the number of events (e.g., absences, diagnoses) per 1,000 "person-years." A "person-year" is a unit of measurement combining persons and time; it is equivalent to one person followed up for 1 year. When an individual worker remains in the work force for the entire year, she or he contributes one personyear to the calculation of rates of disease and injury presented in the report. Rates of disease and injury are often presented as the number of diagnoses or absences from work per thousand workers per year, or per 1,000 person-years.

The statistical methods used to compare the incidence of absences are the relative risk and the $95 \%$ confidence interval.

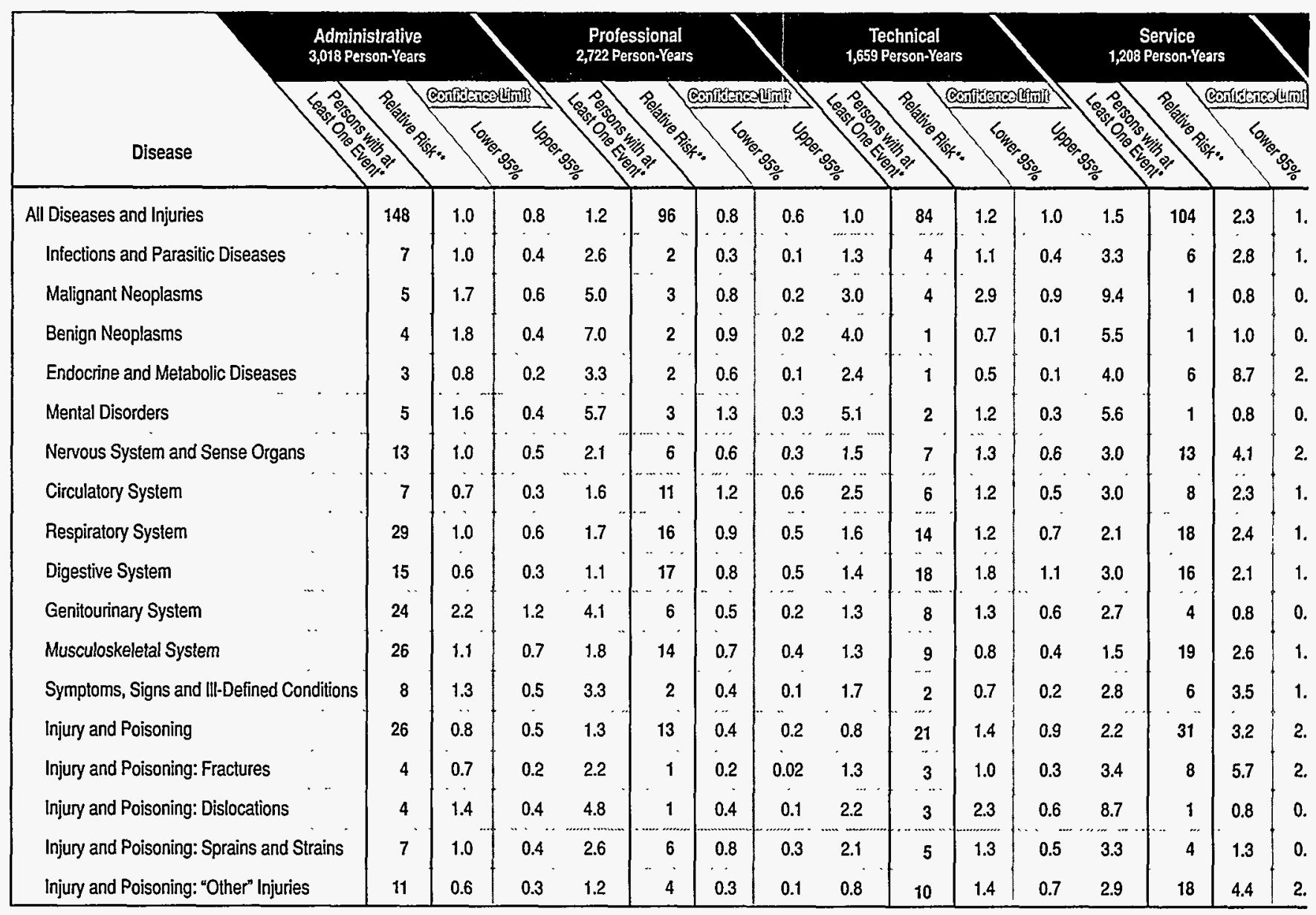

- Persons with multiple absences during the time period were counted only once.

* Adjusted for age and gender - compared with all occupational categories. 
The relative risk is the rate of absence in one group divided by the rate in a reference (comparison) group. The reference group is all workers other than the occupational category of primary interest. A relative risk of 1.0 indicates that both groups have the same risk of absence. A relative risk greater than 1.0 indicates that workers in a selected occupational category have a higher risk of absence than workers in all other occupational categories combined. A relative risk less than 1.0 implies that the selected occupational group has a lower risk of absence compared with all other occupational categories combined.
The confidence interval is a statistical measure of the precision of the risk estimate. A 95\% confidence interval indicates the range in which one would expect the relative risk to fall $95 \%$ of the time. If the confidence interval includes the value 1.0 , then the rate of absence is likely to have occurred by chance; in other words, the relative risk is not statistically significant at the $95 \%$ confidence level. For example, a relative risk of 2.0 with a confidence interval of 0.9 to 2.1 would not be considered statistically significant, whereas a relative risk of 1.4 with a confidence interval of 1.2 to 1.7 would be con- sidered statistically significant. The width of the confidence interval indicates the amount of uncertainty in the risk estimate and is affected by sample size and the number of events in the diagnostic category.

Service workers $(R R=2.3)$ had a statistically significant increased risk of being absent 5 or more consecutive workdays in 1994 due to disease or injury (Table 11). Workers in the unknown category $(R R=0.1)$ had a statistically significant decreased risk of absence.

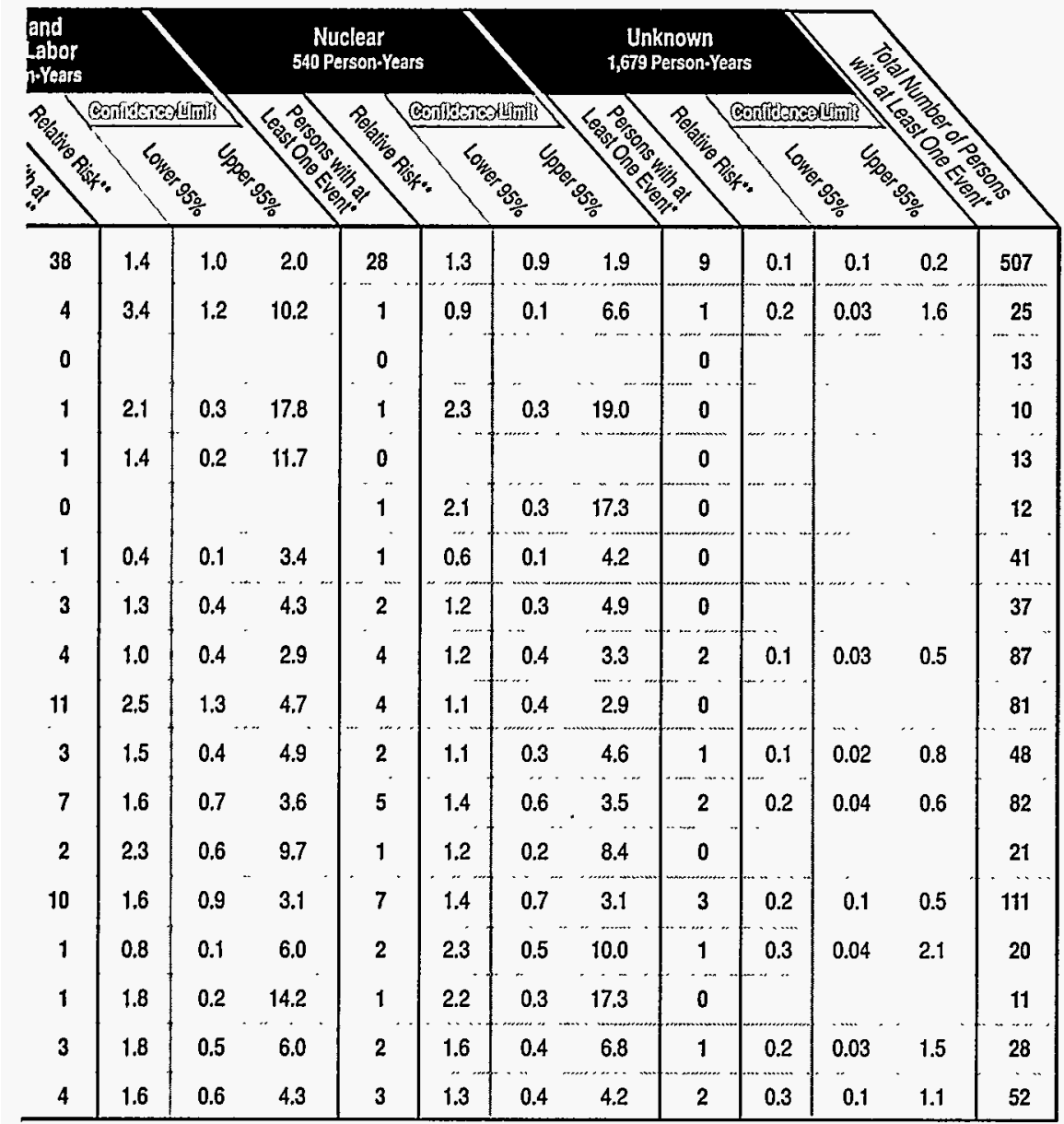

Table 10.

Relative Risk for Selected Disease and Injury Categories by Occupation 


\section{Relative Risk for Selected Disease and Injury Calegories by Occupalion}

Table 10 also presents the relative risks of absences of 5 or more consecutive workdays for selected disease categories among workers by each occupational category.

Administrative workers were significantly more likely to be absent at least once during 1994 for diseases of the genitourinary system (Relative Risk $[R R]=2.2$ ). Technical workers were significantly more likely to be absent at least once during 1994 for diseases of the digestive system $(R R=1.8)$. Service workers had a statistically significant increased risk of being absent due to infections and parasitic diseases $(R R=2.8)$; endocrine and metabolic diseases ( $R R=8.7)$; diseases of the nervous system and sense organs $(R R=4.1)$; diseases of the circulatory system ( $R R=2.3$ ); diseases of the respiratory system ( $R R=2.4)$; diseases of the digestive system $(R R=2.1)$; diseases of the musculoskeletal system ( $R R=2.6)$; symptoms, signs, and illdefined conditions ( $R R=3.5$ ); and injury and poisoning ( $R R=3.2)$, as a whole, with fractures $(\mathrm{RR}=5.7)$ and "other" injuries $(\mathrm{RR}=4.4)$, as subcategories of injury and poisoning. Crafts and manual laborers were found to have a statistically significant elevated risk associated with infections and parasitic diseases $(R R=3.4)$ and diseases of the digestive system $(\mathrm{RR}=2.5)$.

Professional workers were significantly less likely to be absent at least once during 1994 for injury and poisoning ( $R R=0.4)$, as a whole, with "other" injuries ( $R R=0.3)$, as a subcategory of injury and poisoning. Workers in the unknown category had a statistically significant decreased risk of diseases of the respiratory system $(R R=0.1)$; diseases of the genitourinary system $(R R=0.1)$; diseases of the musculoskeletal system $(R R=0.2)$; and injury and poisoning ( $R R=0.2)$, as a whole.

The reasons for the large differences in overall diagnosis rates and relative risks for particular diagnostic cat- egories among different occupational categories may be due to small numbers. However, the consistency of the differences across broad diagnostic categories suggests that compliance with reporting back to work through an occupational physician varies among occupational categories. 
OSHA-Recordable Events Among INEL Employees, 1994 OSHA-Recordable Events per Person. In 1994, 156 INEL employees had at least one OSHA-recordable event. Fifteen (10\%) of these workers had two or more events. There was a total of 173 OSHA-recordable events among all employees (Table 11A.).
Diagnoses per OSHA-Recordable Event. A total of 184 diagnoses were associated with the 173 OSHA events recorded during 1994. Multiple diagnoses were reported for 10 (6\%) of the events (Table 11B.).

Diagnosis Rates for OSHA-

Recordable Events. In 1994, the diagnoses noted for the OSHA

\begin{tabular}{|c|c|c|c|c|c|c|c|}
\hline \multirow{2}{*}{$\begin{array}{l}\text { Employee } \\
\text { Category }\end{array}$} & \multirow{2}{*}{$\begin{array}{l}\text { Number of } \\
\text { Workers } \\
\text { in } 1994\end{array}$} & \multicolumn{4}{|c|}{ Number of OSHA-Recordable Events } & \multirow{2}{*}{$\begin{array}{l}\text { Total } \\
\text { Persons } \\
\text { with at Least } \\
\text { One Event }\end{array}$} & \multirow{2}{*}{$\begin{array}{l}\text { Total } \\
\text { Number of } \\
\text { Events }\end{array}$} \\
\hline & & 0 & 1 & 2 & 3 & & \\
\hline Men & 8,533 & 8,428 & 95 & 8 & 2 & 105 & 117 \\
\hline Women & 2,994 & 2,943 & 46 & 5 & 0 & 51 & 56 \\
\hline TOTAL & 11,527 & 11,371 & 141 & 13 & 2 & 156 & 173 \\
\hline
\end{tabular}

Table 11A.

OSHA-

Recordable

Events per Person

\begin{tabular}{|c|c|c|c|c|c|}
\hline \multirow{2}{*}{$\begin{array}{l}\text { Employee } \\
\text { Category }\end{array}$} & \multicolumn{3}{|c|}{ Number of Diagnoses per OSHA Event } & \multirow{2}{*}{$\begin{array}{l}\text { Total } \\
\text { Number } \\
\text { of Events }\end{array}$} & \multirow{2}{*}{$\begin{array}{l}\text { Total } \\
\text { Number of } \\
\text { Diagnoses }\end{array}$} \\
\hline & 1 & 2 & 3 & & \\
\hline Men & 116 & 1 & 0 & 117 & 118 \\
\hline Women & 47 & 8 & 1 & 56 & 66 \\
\hline TOTAL & 163 & 9 & 1 & 173 & 184 \\
\hline
\end{tabular}

Table $11 B$.

Diagnoses

per OSHA-

Recordable Event

\begin{tabular}{|l|c|c|c|c|c|c|}
\hline $\begin{array}{l}\text { Employee } \\
\text { Category }\end{array}$ & $\begin{array}{l}\text { Number of } \\
\text { Workers } \\
\text { in 1994 }\end{array}$ & $\begin{array}{l}\text { Number of } \\
\text { Diagnoses }\end{array}$ & $\begin{array}{l}\text { Crude } \\
\text { Rate per } \\
1,000\end{array}$ & $\begin{array}{l}\text { Age- } \\
\text { Adjusted } \\
\text { Rate per } \\
1,000^{*}\end{array}$ & $\begin{array}{l}\text { Lower 95\% } \\
\text { Confidence } \\
\text { Limit per } \\
1,000\end{array}$ & $\begin{array}{l}\text { Upper 95\% } \\
\text { Confidence } \\
\text { Limit per } \\
1,000\end{array}$ \\
\hline $\begin{array}{l}\text { Men } \\
\text { Women }\end{array}$ & $\begin{array}{c}8,533 \\
\ldots \ldots \ldots\end{array}$ & 118 & 13.8 & 14.6 & 11.7 & 18.1 \\
\hline TOTAL & 11,994 & 66 & 22.0 & 21.0 & 16.1 & 27.3 \\
\hline
\end{tabular}

Table 11C.

Diagnosis Rates

for OSHA.

Recordable

Events

* Standardized to age distribution of 1970 U.S. population. 


\section{OSHA-Recordable Diseases and Injuries by Diagnostic Calegory, 1994}

The age-adjusted diagnosis rate for each diagnostic category is presented for all workers in Table 12. Tables 13 and 14 show diagnosis rates by gender to further describe the disease and injury patterns in the work force.

For all workers (Table 12), the diagnostic category with the highest rate was injury and poisoning (11.9 per 1,000 ), with 134 diagnoses reported for 122 people, which accounted for $73 \%$ of all the diagnoses. Within this category were two subcategories with relatively high rates. Sprains and strains (6.6 per 1,000), with 74 diagnoses among 67 workers; and "other" injuries (2.9 per 1,000), with 36 diagnoses among 35 workers.

Men. The leading diagnostic category among men (Table 13), accounting for $84 \%$ of all diagnoses, was injury and poisoning (12.5 per 1,000 ), with 99 diagnoses among 90 men. Within this category were three subcategories with relatively high rates. Sprains and strains ( 6.0 per
$1,000)$ accounted for $48 \%$ of these diagnoses, with 48 diagnoses among 44 men. Thirty-two diagnoses were sprains and strains of the back, 11 of the upper extremities, 4 of the lower extremities, and 1 of unspecified sites. Four men had multiple diagnoses. "Other" injuries (3.4 per 1,000 ) accounted for $30 \%$ of the injury and poisoning diagnoses, with 30 diagnoses among 29 men. These included 11 diagnoses for contusions; 8 for heat stress; 6 burns of unspecified degree -3 to the hand, 1 to a finger, and 2 to the lower leg; 3 superficial injuries -1 to the eye and 2 to unspecified sites; 1 bee sting; and 1 broken dentures. One man had multiple diagnoses. Open wounds $(2.6$ per 1,000$)$ accounted for $15 \%$ of the injury and poisoning diagnoses, with 15 diagnoses among 14 men. Of these diagnoses, 11 were for open wounds of the upper extremities, 2 of the lower extremities, and 2 of the cheek. One man had multiple diagnoses.

Women. The diagnostic category with the highest rate was the same among women as for men (Table 14). Injury and poisoning (12.8 per 1,000 ) accounted for $53 \%$ of all diagnoses, with 35 diagnoses among
32 women. Within this category, sprains and strains $(9.2$ per 1,000$)$ accounted for $74 \%$ of these diagnoses, with 26 diagnoses for 23 women. Of these diagnoses, 11 were sprains and strains of the back, 9 of the upper extremities, and 6 of the lower extremities. Three women had multiple diagnoses. Symptoms, signs, and ill-defined conditions ( 4.5 per 1,000 ) had the next highest rate, accounting for $26 \%$ of all diagnoses, with 17 diagnoses among 9 women. The 17 diagnoses included 6 diagnoses for headache, 5 for nausea, 2 for a rash, and 1 each for a cough, chest pain, dizziness and giddiness, and sneezing. Seven women had multiple diagnoses. 


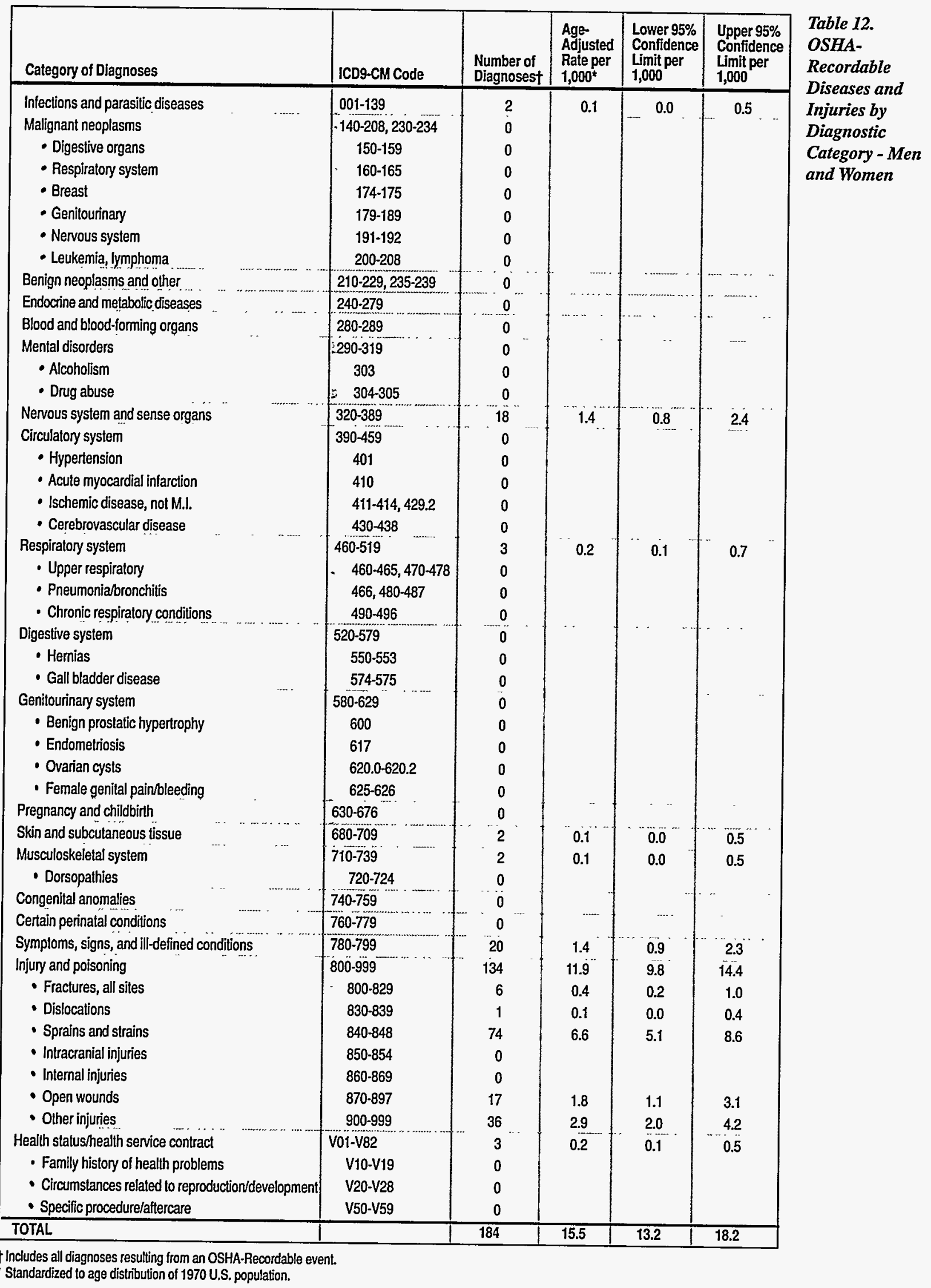




\begin{tabular}{|c|c|c|c|c|c|}
\hline Category of Diagnoses & ICD9-CM Code & $\begin{array}{l}\text { Number of } \\
\text { Diagnoses } \dagger\end{array}$ & $\begin{array}{l}\text { Age- } \\
\text { Adjusted } \\
\text { Rate per } \\
1,000^{*}\end{array}$ & $\begin{array}{l}\text { Lower } 95 \% \\
\text { Confidence } \\
\text { Limit per } \\
1,000\end{array}$ & $\begin{array}{l}\text { Upper } 95 \% \\
\text { Confidence } \\
\text { Limit per } \\
1,000\end{array}$ \\
\hline Infections and parasitic diseases & $001-139$ & 1 & 0.1 & 0.0 & 0.6 \\
\hline Malignant neoplasms & $140-208,230-234$ & 0 & & i & \\
\hline - Digestive organs & $150-159$ & 0 & & $i$ & \\
\hline - Respiratory system & $160-165$ & 0 & & 1 & \\
\hline - Breast & $174-175$ & 0 & & & \\
\hline - Genitourinary & $179-189$ & 0 & & ; & \\
\hline - Nervous system & $191-192$ & 0 & & & \\
\hline - Leukemia, lymphoma & $200-208$ & 0 & & $t$ & \\
\hline Benign neoplasms and other & $210-229,235-239$ & 0 & ' & & \\
\hline Endocrine and metabolic diseases & $240-279$ & 0 & & & \\
\hline Blood and blood-forming organs & $280-289$ & 0 & & & \\
\hline Mental disorders & $290-319$ & 0 & & ' & \\
\hline - Alcoholism & 303 & 0 & & & \\
\hline - Drug abuse & $304-305$ & 0 & & : & \\
\hline Nervous system and sense organs & $320-389$ & 7 & 0.9 & 0.3 & 2.1 \\
\hline Circulatory system & 390.459 & 0 & & & \\
\hline - Hypertension & 401 & 0 & & & \\
\hline - Acute myocardial infarction & 410 & 0 & & & \\
\hline - Ischemic disease, not M.I. & $411-414,429.2$ & 0 & & & \\
\hline - Cerebrovascular disease & $430-438$ & 0 & & $\therefore$ & \\
\hline Respiratory system & $460-519$ & 3 & 0.3 & 0.1 & 0.9 \\
\hline - Upper respiratory & $460-465,470-478$ & 0 & , & & \\
\hline - Pneumoniarbronchitis & $466,480-487$ & 0 & & $!$ & \\
\hline - Chronic respiratory conditions & $490-496$ & 0 & ; & 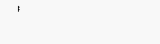 & \\
\hline Digestive system & $520-579$ & 0 & & ; & \\
\hline - Hernias & $550-553$ & 0 & . & $!$ & \\
\hline - Gall bladder disease & $574-575$ & 0 & & $\vdots$ & \\
\hline Genitourinary system & $580-629$ & 0 & & & \\
\hline - Benign prostatic hypertrophy & 600 & 0 & & & \\
\hline - Endometriosis & 617 & NA & & : & \\
\hline - Ovarian cysis & $620.0-620.2$ & NA & & & \\
\hline - Female genital pain/bleeding & $625-626$ & NA & & & \\
\hline Pregnancy and childbirth & $630-676$ & NA & & 1 & \\
\hline Skin and subcutaneous tissue & $680-709$ & 1 & 0.1 & 0.0 & 0.6 \\
\hline Musculoskeletal system & $710-739$ & 2 & 0.2 & 0.0 & 0.7 \\
\hline - Dorsopathies & $720-724$ & 0 & & ' & \\
\hline Congenital anomalies & $740-759$ & 0 & & i & \\
\hline Certain perinatal conditions & $760-779$ & 0 & & i & \\
\hline Symptoms, signs, and ill-defined conditions & $780-799$ & 3 & 0.5 & 0.1 & 2.0 \\
\hline Injury and poisoning & $800-999$ & 99 & 12.5 & 9.8 & 15.8 \\
\hline - Fractures, all sites & $800-829$ & 5 & 0.4 & 0.2 & 1.1 \\
\hline - Dislocations & $830-839$ & 1 & 0.1 & 0.0 & 0.6 \\
\hline - Sprains and strains & $840-848$ & 48 & 6.0 & 4.2 & 8.4 \\
\hline - Intracranial injuries & $850-854$ & 0 & & & \\
\hline - Internal injuries & $860-869$ & 0 & & & \\
\hline - Open wounds & $870-897$ & 15 & 2.6 & 1.4 & 4.7 \\
\hline - Other injuries & $900-999$ & 30 & 3.4 & 2.2 & 5.2 \\
\hline Health status/health service contract & $v_{01-V 82}$ & 2 & 0.2 & 0.0 & 0.7 \\
\hline - Family history of health problems & V10-V19 & 0 & & & \\
\hline - Circumstances related to reproduction/development & V20-V28 & 0 & & i & \\
\hline - Specific procedure/aftercare & V50-V59 & 0 & & 1 & \\
\hline TOTAL & & 118 & 14.6 & 11.7 & 18.1 \\
\hline
\end{tabular}

Table 13.

OSHA-

Recordable

Diseases and

Injuries by

Diagnostic

Category - Men

† Inciudes all diagnoses resulting from an OSHA-Recordable event.

- Standardized to age distribution of 1970 U.S. population. 


\begin{tabular}{|c|c|c|c|c|c|}
\hline Category of Diagnoses & ICD9-CM Code & $\begin{array}{l}\text { Number of } \\
\text { Diagnosest }\end{array}$ & $\begin{array}{l}\text { Age- } \\
\text { Adjusted } \\
\text { Rate per } \\
1,000^{*} \\
\end{array}$ & $\begin{array}{l}\text { Lower } 95 \% \\
\text { Confidence } \\
\text { Limit per } \\
1,000\end{array}$ & $\begin{array}{l}\text { Upper } 95 \% \\
\text { Confidence } \\
\text { Limit per } \\
1,000\end{array}$ \\
\hline Infections and parasitic diseases & $001-139$ & 1 & 0.3 & 0.0 & 2.0 \\
\hline Malignant neoplasms & $140-208,230-234$ & 0 & & & \\
\hline - Digestive organs & $150-159$ & 0 & & & \\
\hline - Respiratory system & $160-165$ & 0 & & & \\
\hline - Breast & $174-175$ & 0 & & & \\
\hline - Genitourinary & $179-189$ & 0 & & & \\
\hline - Nervous system & $191-192$ & 0 & & & \\
\hline - Leukemia, Iymphoma & $200-208$ & 0 & & & \\
\hline Benign neoplasms and other & $210-229,235-239$ & 0 & & & \\
\hline Endocrine and metabolic diseases & $240-279$ & 0 & & & $\cdots$ \\
\hline Blood and blood-forming organs & $280-289$ & 0 & & & \\
\hline Mental disorders & $290-319$ & 0 & & & \\
\hline - Alcoholism & 303 & 0 & & & \\
\hline - Drug abuse & $304-305$ & 0 & & & \\
\hline Nervous system and sense organs & $320-389$ & 11 & 2.9 & 1.6 & 5.5 \\
\hline Circulatory system & $390-459$ & 0 & & & \\
\hline - Hypertension & 401 & 0 & & & \\
\hline - Acute myocardial infarction & 410 & 0 & & & \\
\hline - Ischemic disease, not M.I. & $411-414,429.2$ & 0 & & & \\
\hline - Cerebrovascular disease & $430-438$ & 0 & & & \\
\hline Respiratory system & $460-519$ & 0 & & & \\
\hline - Upper respiratory & $460-465,470-478$ & 0 & & & \\
\hline - Pneumonia/bronchitis & $466,480-487$ & 0 & & & \\
\hline - Chronic respiratory conditions & $490-496$ & 0 & & & \\
\hline Digestive system & 520.579 & 0 & & & \\
\hline - Hernias & $550-553$ & 0 & & & \\
\hline - Gall bladder disease & $574-575$ & 0 & & & \\
\hline Genitourinary system & $580-629$ & 0 & & & \\
\hline - Benign prostatic hypertrophy & 600 & NA & & & \\
\hline - Endometriosis & 617 & 0 & & & \\
\hline - Ovarian cysts & $620.0-620.2$ & 0 & & & \\
\hline - Female genital painbleeding & $625 \cdot 626$ & 0 & & & \\
\hline Pregnancy and childbirth & $630-676$ & 0 & & & \\
\hline Skin and subcutaneous tissue & $680-709$ & 1 & 0.2 & 0.0 & 1.5 \\
\hline Musculoskeletal system & $710 \overline{-739}$ & 0 & & & \\
\hline - Dorsopathies & $720-724$ & 0 & & & \\
\hline Congenital anomalies & $740-759$ & 0 & & & \\
\hline Certain perinatal conditions & $760-779$ & 0 & & & \\
\hline Symptoms, signs, and ill-defined conditions & $780-799^{\circ}$ & 17 & 4.5 & 2.7 & 7.5 \\
\hline Injury and poisoning & $800-999$ & 35 & 12.8 & 8.9 & 18.4 \\
\hline - Fractures, all sites & $800-829$ & 1 & 0.5 & 0.1 & 3.4 \\
\hline - Dislocations & $830-839$ & 0 & & & \\
\hline - Sprains and strains & $840-848$ & 26 & 9.2 & 6.1 & 13.6 \\
\hline - Intracranial injuries & $850-854$ & 0 & & & \\
\hline - Internal injuries & $860-869$ & 0 & & & \\
\hline - Open wounds & $870-897$ & 2 & 1.3 & 0.2 & 7.1 \\
\hline - Other injuries & $900-999$ & 6 & 1.9 & 0.8 & 4.3 \\
\hline Health stalus/health service contract & V01-V82 & 1 & 0.2 & 0.0 & 1.5 \\
\hline - Family history of health problems & V10-V19 & 0 & & & \\
\hline - Circumstances related to reproduction/development & V20-V28 & 0 & & & \\
\hline - Specific procedure/aftercare & V50-V59 & 0 & & & \\
\hline Total minus pregnancies & & 66 & 21.0 & 16.1 & 27.3 \\
\hline TOTAL & & 66 & 21.0 & 16.1 & 27.3 \\
\hline
\end{tabular}

† Includes all diagnoses resulting from an OSHA-Recordable event.

- Standardized to age distribution of 1970 U.S. population.

Table 14.

OSHA-

Recordable

Diseases and

Injuries by

Diagnostic

Category -

Women 
OSHA-Recordable Diagnoses by Occupalional Calegory, 1994

During 1994, the age-adjusted diagnosis rate among all employees was 15.5 per 1,000 persons (Table 15). Crafts and manual laborers, who comprised $6 \%$ of the work force, had the highest diagnosis rate $(80.5$ per 1,000), with 50 diagnoses reported for 46 persons. The second highest diagnosis rate was among service workers (35.1 per 1,000), with 45 diagnoses for 35 persons. Technical workers $(17.6$ per 1,000$)$ ranked third, with 30 diagnoses among 28 workers. Workers whose occupation was unknown had the lowest diagnosis rate (2.2 per 1,000 workers), with four diagnoses for two workers.
Men. The diagnosis rate among men (Table 16) was 14.6 per 1,000 men. Crafts and manual laborers had the highest rate $(89.1$ per 1,000$)$, with 48 diagnoses reported for 44 men. Service workers ranked second (27.1 per 1,000), with 28 diagnoses among 22 men. Nuclear workers followed, with six diagnoses for six men (19.6 per 1,000). The diagnosis rate was the lowest among the workers whose occupation was unknown, with no reported diagnoses.

Women. The diagnosis rate among women (Table 17) was 21.0 per 1,000 . The diagnosis rate for work- ers in the service category (62.8 per 1,000) was the highest, with 17 diagnoses reported among 13 women.

Crafts and manual laborers (28.1 per $1,000)$ ranked second, with two diagnoses for two women. The third highest rate occurred in the category of technical workers (25.8 per 1,000), with 11 diagnoses among 11 women. Workers in the nuclear category had the lowest rate, with no diagnoses reported. 


\begin{tabular}{|c|c|c|c|c|c|}
\hline Occupational Category & $\begin{array}{l}\text { Number of } \\
\text { Workers } \\
\text { in } 1994\end{array}$ & $\begin{array}{l}\text { Number of } \\
\text { Diagnosesf }\end{array}$ & $\begin{array}{l}\text { Age- } \\
\text { Adjusted } \\
\text { Rate per } 1,000^{*}\end{array}$ & $\begin{array}{l}\text { Lower } 95 \% \\
\text { Confidence } \\
\text { Limit per } \\
1,000\end{array}$ & $\begin{array}{l}\text { Upper } 95 \% \\
\text { Confidence } \\
\text { Limit per } \\
1,000\end{array}$ \\
\hline Administrative & 3,018 & 35 & 11.2 & 7.6 & 16.5 \\
\hline Prolessional & 2,722 & 14 & 4.1 & 2.4 & 7.0 \\
\hline Technical & 1,659 & 30 & 17.6 & 11.8 & 26.3 \\
\hline Service & 1,208 & 45 & 35.1 & 24.8 & 49.8 \\
\hline Crafts and Manual Labor & 701 & 50 & 80.5 & 57.3 & 113.0 \\
\hline Nuclear & 540 & 6 & 14.4 & 5.4 & 38.2 \\
\hline Unknown & 1,679 & 4 & 2.2 & 0.8 & 6.0 \\
\hline TOTAL & 11,527 & 184 & 15.5 & 13.2 & 18.2 \\
\hline
\end{tabular}

Table 15.

OSHA-

Recordable

Diagnoses by

Occupational

Category - Men

and Women

\begin{tabular}{|c|c|c|c|c|c|}
\hline Occupational Category & $\begin{array}{l}\text { Number of } \\
\text { Workers } \\
\text { in } 1994\end{array}$ & $\begin{array}{l}\text { Number of } \\
\text { Diagnoses† }\end{array}$ & $\begin{array}{l}\text { Age- } \\
\text { Adjusted } \\
\text { Rate per } 1,000^{*}\end{array}$ & $\begin{array}{l}\text { Lower } 95 \% \\
\text { Confidence } \\
\text { Limit per } \\
1,000\end{array}$ & $\begin{array}{l}\text { Upper } 95 \% \\
\text { Confidence } \\
\text { Limit per } \\
1,000\end{array}$ \\
\hline Administrative & 1,774 & 8 & 6.3 & 2.1 & 19.1 \\
\hline Professional & 2,268 & 9 & 3.2 & 1.7 & 6.3 \\
\hline Technical & 1,252 & 19 & 13.6 & 8.3 & 22.5 \\
\hline Service & 948 & 28 & 27.1 & 16.9 & 43.7 \\
\hline Crafts and Manual Labor & 646 & 48 & 89.1 & 62.3 & 127.5 \\
\hline Nuclear & 460 & 6 & 19.6 & 7.0 & 55.0 \\
\hline Unknown & 1,185 & 0 & & & \\
\hline TOTAL & 8,533 & 118 & 14.6 & 11.7 & 18.1 \\
\hline
\end{tabular}

Table 16.

OSHA-

Recordable

Diagnoses by

Occupational

Category - Men

\begin{tabular}{|c|c|c|c|c|c|}
\hline Occupational Category & $\begin{array}{l}\text { Number of } \\
\text { Workers } \\
\text { in } 1994\end{array}$ & $\begin{array}{l}\text { Number of } \\
\text { Diagnoses† }\end{array}$ & $\begin{array}{l}\text { Age- } \\
\text { Adjusted } \\
\text { Rate per } 1,000^{*}\end{array}$ & $\begin{array}{l}\text { Lower } 95 \% \\
\text { Confidence } \\
\text { Limit per } \\
1,000\end{array}$ & $\begin{array}{l}\text { Upper 95\% } \\
\text { Confidence } \\
\text { Limit per } \\
1,000\end{array}$ \\
\hline Administrative & 1,244 & 27 & 18.6 & 12.6 & 27.6 \\
\hline Professional & 454 & 5 & 5.4 & 2.3 & 13.1 \\
\hline Technical & 407 & 11 & 25.8 & 13.8 & 48.4 \\
\hline Service & 260 & 17 & 62.8 & 37.8 & 104.2 \\
\hline Crafts and Manual Labor & 55 & 2 & 28.1 & 6.5 & 121.9 \\
\hline Nuclear & 80 & 0 & & & \\
\hline Unknown & 494 & 4 & 8.4 & 2.8 & 24.8 \\
\hline TOTAL & 2,994 & 66 & 21.0 & 16.1 & 27.3 \\
\hline
\end{tabular}

Table 17.

OSHA Diagnoses by Occupational Category - Women

t Indudes all diagnoses resulting from an OSHA-recordab'e event.

- Standarcized to age distribution of 1970 U.S, population 
OSHA-Recordable Relaiive Risk for All Diseases and Injuries by Occupation

In Table 18 and Tables 19A through $19 \mathrm{~F}$, the risk of one or more OSHArecordable events associated with selected diagnostic categories for each occupational category is compared with all other occupational categories in the INEL work force. This comparison takes into account the possible confounding effects of age and gender.

In contrast to the previous series of tables, these analyses examine the risk of a worker having one or more OSHA-recordable events during 1994. This was done to minimize the problem associated with one person having multiple events for the same condition. Again, the statistical methods used to compare the incidence of events are the relative risk and the $95 \%$ confidence interval.

Service workers $(R R=2.5)$ and crafts and manual laborers $(R R=7.7)$ had statistically significant increased risks of an OSHA-recordable event in 1994 (Table 18). Administrative workers $(R R=0.6)$, professional workers ( $R R=0.3$ ), and workers in the unknown category $(R R=0.1)$ had statistically significant decreased risks of an event.

\section{OSHA-Recordable Relative Risk for Selected Disease and Injury Calegories by Occupalion}

Tables 19A through 19F present the relative risk of an OSHA-recordable event for selected disease categories among workers by each occupational category.

Examination of the tables shows that service workers were significantly more likely to have at least one OSHA event during 1994 for injury and poisoning $(\mathrm{RR}=2.9)$, as a whole, with sprains and strains $(R R=2.3)$ and "other" injuries $(\mathrm{RR}=6.3)$ as subcategories of injury and poisoning. Crafts and manual laborers were also significantly more likely to have at least one OSHA event during 1994 for injury and poisoning ( $R R=8.9$ ), as a whole, with sprains and strains ( $R R=7.8$ ), open wounds ( $R R=22.6$ ), and "other" injuries ( $R R=6.0)$ as subcategories of injury and poisoning. Administrative workers had a statistically significant decreased risk of having an OSHA-recordable event due to injury and poisoning $(\mathrm{RR}=0.3)$, as a whole, with "other" injuries $(R R=0.1)$ as a subcategory of injury and poisoning. Professional workers were also at a significantly decreased risk for injury and poisoning $(\mathrm{RR}=0.2)$, as a whole, with sprains and strains $(R R=0.2)$ and "other" injuries $(R R=0.3)$ as subcategories of injury and poisoning. Workers in the unknown category were significantly less likely to have an OSHA event due to injury and poisoning $(R R=0.05)$, as a whole, with sprains and strains $(R R=0.1)$ as a subcategory of injury and poisoning.

\begin{tabular}{|c|c|c|c|c|c|}
\hline Occupational Category & Person-Years & $\begin{array}{l}\text { Persons with } \\
\text { at Least One } \\
\text { Event* }\end{array}$ & Relative Risk ${ }^{\star *}$ & $\begin{array}{l}\text { Lower } 95 \% \\
\text { Confidence } \\
\text { Limit }\end{array}$ & $\begin{array}{l}\text { Upper 95\% } \\
\text { Confidence } \\
\text { Limit }\end{array}$ \\
\hline Administrative & 3,018 & 28 & 0.6 & 0.4 & 0.9 \\
\hline Professional & 2,722 & 11 & 0.3 & 0.1 & 0.5 \\
\hline Technical & 1,659 & 28 & 1.3 & 0.8 & 1.9 \\
\hline Senvice & 1,208 & 35 & 2.5 & 1.7 & 3.7 \\
\hline Crafts and Manual Labor & 701 & 46 & 7.7 & 5.3 & 11.1 \\
\hline Nuclear & 540 & 6 & 0.8 & 0.4 & 1.9 \\
\hline Unknown & 1,679 & 2 & 0.1 & 0.02 & 0.3 \\
\hline TOTAL & 11,527 & 156 & & & \\
\hline
\end{tabular}

Table 18. All OSHARecordable Diseases and Injuries by Occupational Categories

- Persons with multiple absences during the time period were counted only once.

** Adjusted for age and gender - compared with all occupational categories. 


\begin{tabular}{|c|c|c|c|c|c|}
\hline Occupational Category & Person-Years & $\begin{array}{l}\text { Persons with } \\
\text { at Least One } \\
\text { Event }\end{array}$ & Relative Risk ${ }^{* \pm}$ & $\begin{array}{l}\text { Lower 95\% } \\
\text { Confidence } \\
\text { Limit }\end{array}$ & $\begin{array}{l}\text { Upper 95\% } \\
\text { Confidence } \\
\text { Limit }\end{array}$ \\
\hline Administrative & 3,018 & 7 & 1.3 & 0.5 & 3.2 \\
\hline Prolessional & 2,722 & 3 & 0.8 & 0.2 & 2.8 \\
\hline Technical & 1,659 & 1 & 0.4 & 0.05 & 2.6 \\
\hline Service & 1,208 & 3 & 2.0 & 0.6 & 6.9 \\
\hline Crafts and Manual Labor & 701 & 1 & 1.3 & 0.2 & 8.8 \\
\hline Nuclear & 540 & 2 & 3.5 & 0.7 & 16.1 \\
\hline Unknown & 1,679 & $i$ & 0.3 & 0.05 & 2.5 \\
\hline TOTAL & 11,527 & 18 & & & \\
\hline
\end{tabular}

\begin{tabular}{|c|c|c|c|c|c|}
\hline Occupational Category & Person-Years & $\begin{array}{l}\text { Persons with } \\
\text { at Least One } \\
\text { Event }^{\star}\end{array}$ & Relative Risk ${ }^{\mathbf{}}$ & $\begin{array}{l}\text { Lower } 95 \% \\
\text { Confidence } \\
\text { Limit }\end{array}$ & $\begin{array}{l}\text { Upper } 95 \% \\
\text { Confidence } \\
\text { Limit }\end{array}$ \\
\hline Administrative & 3,018 & 5 & 1.4 & 0.4 & 4.9 \\
\hline Professional & 2,722 & 3 & 1.4 & 0.4 & 5.2 \\
\hline Technical & 1,659 & 1 & 0.5 & 0.1 & 4.0 \\
\hline Service & 1,208 & 1 & 0.9 & 0.1 & 7.1 \\
\hline Crafts and Manual Labor & 701 & 1 & 2.6 & 0.3 & 22.2 \\
\hline Nuclear & 540 & 0 & & & \\
\hline Unknown & 1,679 & 1 & 0.5 & 0.1 & 4.0 \\
\hline TOTAL & 11,527 & 12 & & & \\
\hline
\end{tabular}

\begin{tabular}{|c|c|c|c|c|c|}
\hline Occupational Category & Person-Years & $\begin{array}{l}\text { Persons with } \\
\text { at Least One } \\
\text { Event }^{\star}\end{array}$ & Relative Risk ${ }^{\star \star}$ & $\begin{array}{l}\text { Lower } 95 \% \\
\text { Confidence } \\
\text { Limit }\end{array}$ & $\begin{array}{l}\text { Upper } 95 \% \\
\text { Confidence } \\
\text { Limit }\end{array}$ \\
\hline Administrative & 3,018 & 14 & 0.3 & 0.2 & 0.6 \\
\hline Prolessional & 2,722 & 6 & 0.2 & 0.1 & 0.4 \\
\hline Technical & 1,659 & 25 & 1.5 & 1.0 & 2.3 \\
\hline Service & 1,208 & 31 & 2.9 & 1.9 & 4.4 \\
\hline Crafts and Manual Labor & 701 & 41 & 8.9 & 5.9 & 13.2 \\
\hline Nuclear & 540 & 4 & 0.7 & 0.3 & 1.9 \\
\hline Unknown & 1,679 & 1 & 0.05 & 0.01 & 0.3 \\
\hline TOTAL & 11,527 & 122 & & & \\
\hline
\end{tabular}

\begin{tabular}{|l|r|r|r|r|c|}
\hline Occupatlonal Category & Person-Years & $\begin{array}{l}\text { Persons with } \\
\text { at Least One }^{\text {Event }^{*}}\end{array}$ & Relative Risk & $\begin{array}{l}\text { Lower 95\% } \\
\text { Confidence } \\
\text { Limit }\end{array}$ & $\begin{array}{l}\text { Upper 95\% } \\
\text { Confidence } \\
\text { Limit }\end{array}$ \\
\hline Administrative & 3,018 & 12 & 0.5 & 0.3 & 1.0 \\
Prolessional & 2,722 & 3 & $\ldots .2$ & 0.05 & 0.5 \\
Technical & 1,659 & 14 & 1.6 & 0.9 & 2.8 \\
Service & 1,208 & 14 & 2.3 & 1.3 & 4.1 \\
Crafts and Manual Labor & 701 & 19 & 7.8 & 4.4 & 13.9 \\
Nuclear & 540 &.- .3 & 1.3 & 0.5 & 3.7 \\
Unknown & 1,679 & 1 & 0.1 & 0.01 & 0.6 \\
\hline TOTAL & 11,527 & 67 & & & \\
\hline
\end{tabular}

Table 19C.

Injury and Poisoning

Symptoms, Signs and Ill-Defined

Conditions

- Persons with multiple absences during the time period vere counted only once.

* Adjusted for age and gender - compared with all occupational categories. 


\begin{tabular}{|c|c|c|c|c|c|}
\hline Occupational Category & Person-Years & $\begin{array}{l}\text { Persons with } \\
\text { at Least One } \\
\text { Event }^{\star}\end{array}$ & Relative Risk ${ }^{\text {t* }}$ & $\begin{array}{l}\text { Lower 95\% } \\
\text { Confidence } \\
\text { Limit }\end{array}$ & $\begin{array}{l}\text { Upper } 95 \% \\
\text { Confidence } \\
\text { Limit }\end{array}$ \\
\hline Administrative & 3,018 & 0 & & & \\
\hline Professional & 2,722 & 0 & & & \\
\hline Technical & 1,659 & 3 & 1.2 & 0.4 & 4.2 \\
\hline Service & 1,208 & 3 & 1.9 & 0.5 & 7.0 \\
\hline Crafts and Manual Labor & 701 & 10 & 22.6 & 8.0 & 63.4 \\
\hline Nuclear & 540 & 0 & & & \\
\hline Unknown & 1,679 & 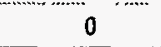 & & & \\
\hline TOTAL & 11,527 & 16 & & & \\
\hline
\end{tabular}

Table 19E.

Injury and

Poisoning:

Open Wounds

\begin{tabular}{|c|c|c|c|c|c|}
\hline Occupational Category & Person-Years & $\begin{array}{l}\text { Persons with } \\
\text { at Least One } \\
\text { Event }^{*}\end{array}$ & Relative Risk* & $\begin{array}{l}\text { Lower } 95 \% \\
\text { Confidence } \\
\text { Limit }\end{array}$ & $\begin{array}{l}\text { Upper } 95 \% \\
\text { Confidence } \\
\text { Limit }\end{array}$ \\
\hline Administrative & 3,018 & 1 & 0.1 & 0.01 & 0.7 \\
\hline Professional & 2,722 & 3 & 0.3 & 0.1 & 0.9 \\
\hline Technical & 1,659 & 6 & 1.2 & 0.5 & 2.9 \\
\hline Service & 1,208 & 15 & 6.3 & 3.2 & 12.5 \\
\hline Crafts and Manual Labor & 701 & 10 & 6.0 & 2.8 & 12.8 \\
\hline Nuclear & 540 & 0 & & & \\
\hline Unknown & 1,679 & 0 & & & \\
\hline TOTAL & 11,527 & 35 & & & \\
\hline
\end{tabular}

Table 19F.

Injury and

Poisoning:

“Other" Injuries

- Persons with multiple absences during the time period were counted only once.

*Adjusted for age and gender - compared with all occupational categories. 
Jegory of Diagnoses

ICD-9-CM Code Types of Illiness in Cufegory

conditions

$001-\mathrm{V} 82$

All reported health events.

ectious and parasitic diseases

$001-139$

Diseases caused by bacteria, viruses, and parasites.

Jignant neoplasms

$230-234$

All cancers, regardless of the part of the body affected.

210-229, Tumors that are not cancerous or that do not exhibit clearly malignant behavior, regardess 235-239 of the part of the body affected.

nign neoplasms and neoplasms of uncertain havior and unspecified nature

$240-279$

Diseases and conditions affecting the hormone secreting glands and organs; nutritional disorders, such as vitamin deficiency: metabolic diseases, such as diabetes and gout; and problems affecting the antibody producing system.

'orders of the immune system

280.289 Includes anemia and hemophilia, but excludes leukemia.

leases of the blood and blood-forming organs

intal disorders

290-319 Psychiatric diagnoses, such as dementia, schizophrenia, depression, and anxiefy disorders; alcoholism; drug dependence; and eating disorders, such as bulimia.

feases of the nervous system and sense organs

$320-389$

Diseases affecting the brain, spinal cord, and peripheral nerves. Examples include meningitis; encephalitis; hereditary diseases, such as Huntington's chorea; Alzheimer's and Parkinson's disease; epilepsy; multiple sclerosis; migraine; diseases of the eye, such as cataract and glaucoma; and diseases of the ear, such as conductive hearing loss and otitis.

Seases of the circulatory system

$390-459$

Diseases involving the heart, arteries, veins, and lymphatic system. Examples include meumatic fever, heart murmurs, heart attacks, angina, hardening of the arteries, varicose veins, hemorrhoids, and phlebitis.

eases of the respiratory system

460.519 Includes colds, sinusitis, laryngitis, pneumonia and influenza, chronic bronchitis, asthma, and emphysema.

eases of the digestive system

520.579 Diseases affecting the teeth and mouth, salivary glands, digestive tract, and the abdominal cavity. Examples include dental abscess, ulcers, appendictitis, hepatitis (excluding viral hepatitis), cirrhosis of the liver, gallstones, pancreatitis, abdominal hernia, and intestinal polyps.

;eases of the genitouninary system

580-629 Diseases affecting the kidneys, the prostrate, and testes; benign breast diseases; infertility (male and female); pelvic inflammatory disease; diseases of the ovary; and menstrual disorders.

implications of pregnancy, childbith, and

esperium

630-676 Includes miscarriage; complications of pregnancy, such as hemorhage; pregnancy-related high blood pressure; pre-eclampsia; premature labor or other complications of labor.

Seases of the skin and subcutaneous tissue

$680-709$

Includes acne, cellulitis, sunburn, psoriasis, and seborrhea.

seases of the musculoskeletal system and

nnective tissue

710-739 Includes arthrits, systemic lupus erythematosus, ankylosing spondylitis, herniated intervertebral disc ("Slipped disc)", lumbago, sciatica, meumatism, tendinitis, and osteoporosis.

ungenital anomalies

$740-759$

Abnormal anatomical development present at birth. Includes spina bifida, cleft palate, harelip. and various chromosomal anomalies, such as Klinefelter's syndrome.

Ittain conditions originating in the perinatal period

$760-779$

Conditions or diseases of the mother that can produce perinatal iliness or death of the fetus or newborn. Examples include maternal high blood pressure, maternal malnutrition, ectopic pregnancy, and breech birth. Also includes other conditions originating in the perinatal period, such as fetal malnutrition or slow growth, injuries related to birth trauma, and perinatal jaundice.

mptoms, signs, and ill-defined conditions

$780-799$

Symptoms, signs, abnormal results of laboratory or other tests, and conditions for which no specific diagnosis has been made. Examples include blackout, chills, dizziness, fatigue, pallor, abnormal weight loss, undiagnosed chest pain, and heartburn.

ury and poisoning

$800-999$

Dislocation of joints; sprains and strains of joints and associated muscles; concussions; bruises; cuts; internal injuries due to crushing, puncture, tearing, or blunt impact; burns; blisters; poisoning; frostbite; heat stroke; and complications of medical or surgical care.

actures, all siles

$800-829$

Cracks or breaks of any bone.

830-839 Separation of a bone from its normal socket or joint

slocation

rains and strains of joints and adjacent muscles

$840-848$

Strains include injuries to muscle from overexertion or from stretching the muscle beyond its normal limit. Sprains include injuries involving tearing or overextending the ligaments of a joint.

racranial injuries excluding those with skull

ctures

ernal injuries of the chest, abdomen, and pelvis

$850-854$

Includes concussions, internal bruises, and hemorrhages within the skull without a fracture of the bones of the skull.

860-869 Includes internal injuries to the chest, abdomen, and pelvis and the organs within these areas of the body that do not involve an open wound.

Sen wounds

870-897 Includes animal bites, cuts, lacerations, punctures, and amputations, excluding the arteries and veins.

her injuries and effects of external causes

$900-999$

Miscellaneous injuries, including injuries to the arteries and veins, problems that occur an extended period of time after the injury has taken place ("late effects"), supericial bruises and abrasions, burns, post-injury shock, poisoning, toxic side effects of chemicals, heat stroke, electrocution, and altitude sickness.

glor vehicle traffic accldents

E810-E819 Includes accidents involving motor vehicles alone or with other motor vehicles, pedestrians, or vehicles operated by pedals.

her accidents

E916-E928 Includes accidents involving falling objects or machinery; accidents related to explosions: and those related to electrical current, radiation, hot or corrosive substances, noise, and overexertion

V10-V19 Covers situations in which the person is not ill or injured but has a personal or family history of problems, such as cancer, mental illness, allergies, or arthritis, that may affect his or her of problems,
nisk of illness.

pamily history of disease

ipplementary classifications related to health care preproduction and child development

V20-V28 Includes problems related to pregnancy, postpartum care, contraception, outcome of delivery and physical development of child.

V50-V59 Includes care for workers who have been treated previously for an illness or injury that is no onger present but who receive care to complete treatment or prevent recurrence.
Adjustment - A mathematical

procedure for rates in which the effects of differences (such as age) in groups have been removed. The purpose of adjustment is to allow comparisons

between two or more groups.

Epidemiologic Surveillance - The regular and systematic collection of data and interpretation of the distribution of illness, injury, and death in the DOE labor force over time.

ICD-9-CH - The ICD-9-CM (International Classification of Diseases-9th Revision-Clinical Modification) is based on the ICD-9 originally published by the World Health Organization and widely accepted as a standard for the coding of cause of death. The ICD-9-CM is required for the reporting of morbidity to all U.S. Public Health Service programs.

Diagnoses Rate - The number of new, reported health events observed among DOE workers per thousand DOE workers at risk during a given period of time.

Person-yeur - A unit of measurement combining persons and time equivalent to one person followed up for one year. In Epidemiologic Surveillance reports, rates are often expressed as the number of events (e.g., illness absences, injuries) per 1,000 personyears.

\section{StATISTIGAL NOTE}

The age-adjusted rate was calculated using the 1970 U.S. population. The age-adjusted rate represents the hypothetical rate that would have been observed if the 1993 group had the same age distribution as the 1970 U.S. population. The age-adjusted rate is used to compare populations that differ in age. The 1970 U.S. population was selected because it is the standard most used for published morbidity data.

The illness and injury absence rate is defined as an absence due to illness or injury of 5 or more conseculive work days, divided by the total number of workers. OSHA-recordable events may or may not involve an absence fromwork.

The $95 \%$ confidence interval is based on the normal approximation to the binomial distribution where the calculated illness and injury absence rate falls within the interval. The true rate lies within this interval $95 \%$ of the time. 